\title{
Mystery Cults and Visual Language in Graeco-Roman Antiquity: An Introduction
}

\author{
Nicole Belayche and Francesco Massa
}

Like the attendants at the rites, who stand outside at the doors [...] but never pass within.

DIO CHRYSOSTOMUS

Behold, I have related things about which you must remain in ignorance, though you have heard them.

APULEIUS ${ }^{1}$

These two passages from two authors, one writing in Greek, the other in Latin, set the stage of this book on Mystery cults in Visual Representation in Graeco-Roman Antiquity. In this introductory chapter we begin with a broad and problematizing overview of mystery cults, stressing the original features of "mysteries" in the Graeco-Roman world - as is to be expected in this collection, and as is necessary when dealing with this complex phenomenon. Thereafter we will address our specific question: the visual language surrounding the mysteries.

It is a complex and daunting challenge to search for ancient mysteries, ${ }^{2}$ whether represented textually or visually, whether we are interested in their

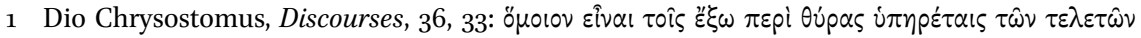
[...] oủ 23: Ecce tibi rettuli, quae, quamvis audita, ignores tamen necesse est (transl. J. Gwyn Griffiths, Apuleius of Madauros, The Isis-Book (Metamorphoses, bookXI) (Leiden, Brill: 1975), 99).

2 Thus the program (2014-2018) developed at the research center AnHiMA (UMR 8210, Paris) on "Mystery Cults and their Specific Ritual Agents", in collaboration with the programs "Ambizione" and "Eccellenza", funded by the Swiss National Science Foundation (SNSF) and hosted by the University of Geneva (2015-2018) and University of Fribourg (2019-2023). See 
material aspects, or in the notion of "mystery" itself. ${ }^{3}$ In essence, the word "mysteries" designates religious practices that were kept secret by their worshippers, who were in turn called "initiates". ${ }^{4}$ Yet the term mysteria (vel sim.) has also been used in historiography to convey a wide range of conceptions in diverse fields: psychology (the approach to the divine), epistemology (access to knowledge inaccessible through the normal means of daily ritual or dialectic reasoning), and social constructionism (a common identity created within a group of initiates).

These peculiarities in terms of missing evidence and religious complexity likely explain why mystery cults - previously referred to as "mystery religions" ("Mysterienreligionen" / "religions à mystères" by both Richard Reitzenstein and Franz Cumont, see infra $)^{5}$ - have prompted such a rich quantity of studies 6 and scholarly debates on their nature, content(s) and purposes, to the extent that their very historicity has been questioned by some - and including a model which postulated a general shift from late pagan cults to "mystery cults". ${ }^{7}$ These numerous studies were in part inspired by the development of

Nicole Belayche and Francesco Massa (eds.), Les «mystères »: questionner une catégorie, Mètis N.S. 14 (2016), 7-132.

3 "Le mystérieux" (the feeling of mystery) was a structural frame of religion for Émile Durkheim, Les formes élémentaires de la vie religieuse. Le système totémique en Australie (Paris: Félix Alcan, 1912), 36 ("La religion définie par le surnaturel et le mystérieux"); yet it concerned a definition of divine alterity and not specific cultic organisations or realities.

4 Cf. Georg Simmel, "The Secret and the Secret Society," in Kurt H. Wolff (ed.), The Sociology of Georg Simmel (New York: Free Press, 1950), 305-76; Pierre Vesperini, Lucrèce. Archéologie d'un classique européen (Paris: Fayard, 2017), 17: the $\mu \nu \sigma \tau \eta \dot{p} ı$ as "fêtes du silence". Yet not all secret cults were mysteries (cf. the vetusta occultaque sacra of Bona Dea at Rome, Philippe Moreau, Clodiana religio. Un procès politique en 61 avant J.-C. [Paris: Les Belles Lettres, 1982], 11-5; Hendrik H. J. Brouwer, Bona Dea. The Sources and a Description of the Cult [Leiden: Brill, 1989], and Attilio Mastrocinque, Bona Dea and the Cults of Roman Women [Stuttgart: Franz Steiner, 2014], 74-81), except if one uses an extensive definition, and not all rituals called "mysteries" were secret, cf. the "imperial mysteries", Jan N. Bremmer, "Imperial Mysteries," Mètis N.s. 14 (2016), 21-34 and Nicole Belayche, "Religions de Rome et du monde romain," Annuaire, Résumés des conférences et travaux, EPHE, Section des Sciences religieuses 124 (2015-2016), 131-8, esp. 132-5.

5 Giulia Sfameni Gasparro, Misteri e teologie. Per la storia dei culti mistici e misterici nel mondo antico (Cosenza: Giordano, 2003), 233-47, poses the question anew for the mysteries of Mithras.

6 Besides all the studies referred to below, we may note in these last years a conference held at Emory University in 2002: Sandra Blakely (ed.), "Proceedings of the Conference on the Mysteries," Electronic Antiquity 12, 1 (2009), http://scholar.lib.vt.edu/ejournals/ElAnt/V12N1/; and another in Strasbourg, which investigated these conceptions in texts from a comparative perspective: Marc Philolenko, Yves Lehmann, and Laurent Pernot (eds.), Les Mystères: nouvelles perspectives. Entretiens de Strasbourg (Turnhout: Brepols, 2017).

7 For $\tau \dot{\alpha} \mu \nu \sigma \tau \eta \dot{p} 1 \alpha$ as a concept in the history of religions, see below p. 17-25. 
a complex lexicon or imaginaire relating to the mysteries in Greek and Latin literature of the Roman period from the end of the first century onwards. ${ }^{8}$ In 2018, we proposed to call this trend a "mystérisation". ${ }^{9}$ Among the many authors who participated in the process, Lucian of Samosata represents an apogee in both lexicon and narratives, precisely because he does so through humour. In his Tragodopodagra, he depicts patients with gout as initiates of the deity: "And we your devotees, O Gout, an offering of groans now pays to you

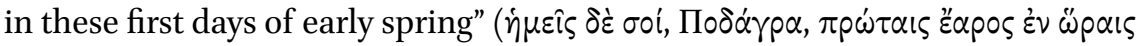

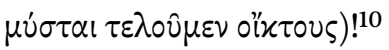

Mystery cults have long been a major concern in scholarship, and have been identified as a major feature of the religious evolutions of the Roman Empire."11 And so, it is surprising that the issue of depiction(s) or visual evocation(s) of mysteries and initiatory experiences has not yet been engaged directly, with the exception of a few case studies pertaining to the cult of Mithras. This fact is all the more surprising when we consider that certain mysteries are regularly, and primarily, reconstructed on the basis of images, despite "the opacity of [their] iconography". ${ }^{2}$ At the beginning of the twentieth century, this

8 See new words like $\mu \nu \sigma \tau \eta \rho เ \omega \delta \eta \emptyset$, used by authors from the age of Plutarch onwards, infra n. 45. For a mystery-like picture of the philosophical cursus, see Geert Roskam, "And a great silence filled the temple ...: Plutarch on the connections between mystery cults and philosophy," in Aurelio Pérez Jiménez and Francesc Casadesús Bordoy (eds.), Estudios sobre Plutarco: misticismo y religiones mistéricas en la obra de Plutarco (Madrid: Ediciones Clásicas, 2001), 221-32; Maria José Martin-Velasco and Maria José Garcia Blanco (eds.), Greek Philosophy and Mystery Cults, (Cambridge: Cambridge University Press, 2016); Jan N. Bremmer, "Philosophers and the Mysteries," in Christoph Riedweg (ed.), Philosophia in der Konkurrenz von Schulen, Wissenschaften und Religionen: Zur Pluralisierung des Philosophiebegriffs in Kaiserzeit Und Spätantike (Berlin-Boston: De Gruyter, 2017), 99-126; Francesco Massa and Nicole Belayche (eds.), Les philosophes et les "mystères" dans l'empire romain (Liège: Presses Universitaires de Liège, forthcoming). For rhetorical literature, Roderich Kirchner, "Die Mysterien der Rhetorik. Zur Mysterienmetapher in rhetoriktheoretischer Texten," Rheinisches Museum 148 (2005), 165-80.

9 Nicole Belayche, Francesco Massa and Philippe Hoffmann (eds.), Les mystères au II ${ }^{e}$ siècle de notre ère: un tournant? (Turnhout: Brepols, 2020).

10 Lucian, Tragodopodagra, 42-44 (transl. LCL modified); see also 111: "And what the rites

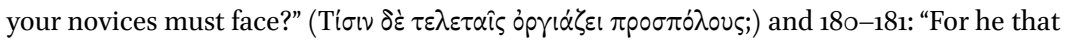
shareth in my mystic rites learns first and that right soon to curb his tongue" ( $\dot{\delta} \gamma \dot{\alpha} \rho \mu \varepsilon \tau \alpha-$

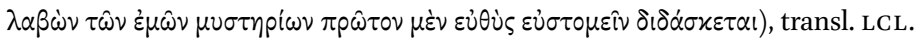

11 For an overview of the broad theoretical and historiographical lines of the notion of "mystery cults", see Nicole Belayche and Francesco Massa, "Quelques balises introductives: lexique et historiographie," Mètis N.s. 14 (2016), 7-19.

12 Richard Gordon, Image and Value in the Graeco-Roman World. Studies in Mithraism and Religious Art (Aldershot, Brookfield: Variorum, 1996), IV, 46. 
was Franz Cumont's method for deciphering the mysteries of Mithras, and this method has remained dominant, despite major recent re-examinations: ${ }^{13}$

nous ne connaissons guère ces traditions épiques [i.e. those of the doctrines of the mysteries] que par les monuments qui leur servaient d'illustration. ${ }^{14}$

In his wake, Robert Turcan was more definitive in calling Mithraic images "de véritables 'histoires saintes' en images". ${ }^{15}$ The reader will detect a Christian flavour in his choice of words. Yet, from the 1970's onwards, another trend developed which demonstrated a simultaneously semiotic and astronomical reading of Mithriac iconography, rooted on the works of Roger Beck and Richard Gordon. ${ }^{16}$

Aware of this background, this book aims to fill a gap in the study of mystery cults, insofar as it focuses only on the visual language as a tool to further consideration of "a" mystery, or of mystery-related features, and illuminating (where possible) the rituals of the mystery cults of Graeco-Roman Antiquity. The question of visual representation of the mysteries is broader than the field of the history of religions. It engages larger historical issues when considering, for example, how two verses of Statius, evoking the Mithraic tauroctony, ${ }^{17}$ have served as a basis for casting the city of Rome in the 8 os as the cradle of "Mithraism", twenty years before the first undisputed relief. ${ }^{18}$ Addressing

13 For the concept of "religions orientales", see the critical introduction in Franz Cumont, Les religions orientales dans le paganisme romain, Corinne Bonnet and Françoise Van Haeperen (eds.) (repr. of the 1929, fourth, French edition) (Turin: Aragno, 2006), XXXIV-XLIV.

14 Franz Cumont, Les Mystères de Mithra, Nicole Belayche and Attilio Mastrocinque (eds.) (Turin-Turnhout: Aragno-Brepols, 2013) [repr. of the 1913, third, French edition], 101 (we underline).

15 Robert Turcan, Mithra et le mithriacisme (Paris: Les Belles Lettres, 1993), 45: "[1]e mithriacisme nous est accessible surtout et directement par l'iconographie".

16 Roger Beck, The Religion of the Mithras Cult in the Roman Empire: Mysteries of the Unconquered Sun (Oxford: Oxford University Press, 20o6). For a cognitive reading, Olympia Panagiotidou and Roger Beck, The Roman Mithras Cult: A Cognitive Approach (Oxford: Oxford University Press, 2017). Recently Richard Gordon, "From East to West: Staging Religious Experience in the Mithraic Temple," in Svenja Nagel, Joachim Friedrich Quack, and Christian Witschel (eds.), Entangled Worlds: Religious Confluences between East and West in the Roman Empire. The Cult of Isis, Mithras, and Jupiter Dolichenus (Tübingen: Mohr Siebeck, 2017), 413-42.

17 Statius, Thebaid, 1, 719-720: "Mithras, that beneath the rocky Persian cave strains at the reluctant-following horns (Seu Persei sub rupibus antri / Indignata sequi torquentem cornua Mithram)", transl. LCL.

18 CIMRM 594, that of Alcimus (c. 102), a slave vilicus of the Praetorian Prefect Ti. Claudius Livianus, dedicated Sol(i) M(ithrae). 
mystery cults on the basis of the visual expressions of their realia or conceptions (ennoia) might offer a path for supplementing the paucity of textual evidence for ritual praxis, due to the rule of silence. Focused on images - and the additional challenge of distinguishing between cultural (i.e. framed by paideia) and ritual imagery -, this volume has no pretentions of being an exhaustive survey of mystery cults as a whole. ${ }^{19}$ For this reason it does not address mystery cults that have (as far as we know) left no images, like those of the Great Gods in Samothrace, ${ }^{20}$ or the Orphic "mysteries" for which there is no clear historical evidence (notwithstanding the debate over Orphism as itself a "mystery") ${ }^{21}$ and do not seem to have been particularly secretive, when one considers the large diffusion of Orphic fragments. ${ }^{22}$

Studying Mysteries: The Paradoxical Study of a Concealed Object

During the reign of Marcus Aurelius, Lucian reports the challenge set by Demonax regarding the rule of secrecy: mysteries should be revealed, because they are either "vain" $(\varphi \alpha \hat{\nu} \lambda \alpha)$, or, for the sake of $\varphi i \lambda \alpha \nu \theta \omega \omega \pi i \alpha$, because they are "good" $(\kappa \alpha \lambda \dot{\alpha}) .{ }^{23}$ Scholars (who do not of course have to choose) are faced by the paradoxes both of these alternatives, and of the object itself. In fact, evidence for the mysteries demonstrates discourses concerning that which is known by all and that which is reserved to few, ${ }^{24}$ that which must be concealed even though it is widely known, that which is shown and that which is hidden,

19 After the seminal work of Walter Burkert, Ancient Mystery Cults (Cambridge, MA-London: Harvard University Press, 1987), more recent attempts include Hugh Bowden, Mystery Cults of the Ancient World (Princeton, NJ: Princeton University Press, 2010) and Jan N. Bremmer, Initiation into the Mysteries in Ancient World (Berlin-Boston: De Gruyter, 2014).

20 The association of the Megaloi theoi and the Cabiroi adds confusion to an already complex dossier, for the Cabiroi were considered as a mythological matrix for mystery behaviour, see Emiliano Cruccas, Gli dei senza nome. Sincretismi, ritualità e iconografia dei Cabiri e dei Grandi Dei tra Grecia e Asia Minore (Rahden: Westf, 2014) and Nicole Belayche, "Strabon historien des religions comparatiste dans sa digression sur les Courètes," Revue de l'histoire des religions 234, 4 (2017), 613-33.

21 On Orphism as a basis for the representation of mystery from the Renaissance to the nineteenth century at least, see recently Philippe Borgeaud, "L'invention de la religion grecque," Kernos 30 (2017), 9-35, esp. 11-4.

22 Cf. Martin West, The Orphic Poems (Oxford: Clarendon Press, 1983); contra Claude Calame, "Qu'est-ce qui est orphique dans les Orphika?," Revue de l'histoire des religions 219, 4 (2002), 385-400.

23 Lucian, Demonax, 11, 18-24.

24 Athenaeus, Deipnosophists, 3, 54, 10-11, quotes an original etymology attributed to

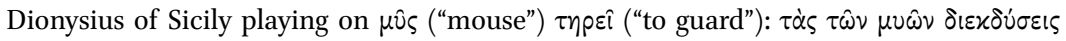


that which is said and that which is unsaid, and that which was deliberately presented in a veiled form, as in Plutarch's philosophical perspective. ${ }^{25}$ When they are envisioned from a sociological perspective (based on American, and contemporary, sectarian movements), these processes have been conceptualised as dichotomies which operate within strictly hierarchical groups, with structured relationships between the initiates: knowledge/ignorance (with consequences for in-group hierarchy according to progressive initiation, as in Mithraic communities), insiders/outsiders, visible/invisible, or revelation/ concealment. ${ }^{26}$

Plutarch stresses many times the fact that the two kinds of religious

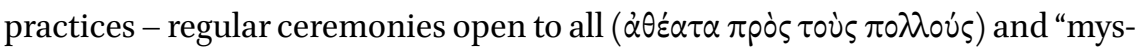

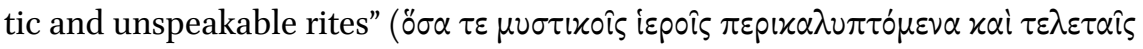

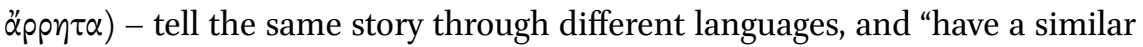

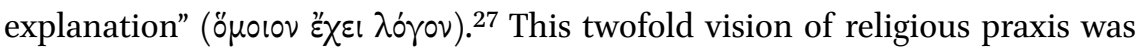
a shared conception among Greek and Roman thinkers, echoing to a twofold ritual access to the divine:

Now this is common (Kovvóv) both to the Greeks and to the barbarians,

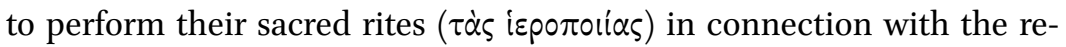
laxation of a festival ( $\mu \varepsilon \tau \dot{\alpha} \alpha \dot{\alpha} \varepsilon \dot{\sigma \varepsilon \omega \varsigma} \dot{\varepsilon} о \rho \tau \alpha \sigma \tau \imath \kappa \hat{\eta} \varsigma)$, these rites being performed sometimes with religious frenzy, sometimes without it ( $\tau \dot{\alpha} \varsigma \mu \dot{\varepsilon} \nu$

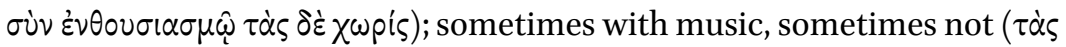

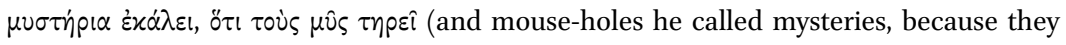
keep the mice).

25 Plutarch, fr. 157 Sandbach, $15^{-25}$ (On the Festival of the Images at Plataeae), ap. Eusebius, Preparation for the Gospel, 3, Prooem.: "a theology such as is found in mystery ceremonies

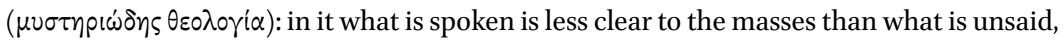
and what is unsaid gives cause for more speculation than what is said. This is evident from the Orphic poems and the accounts given by Phrygians and Egyptians. But nothing does

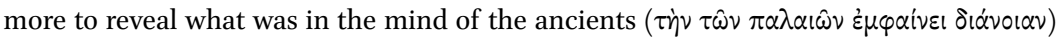

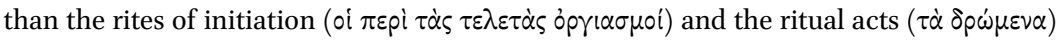

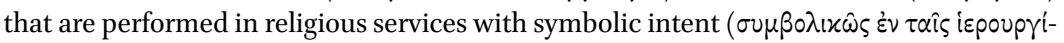

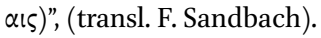

26 See the Weberian analysis of "sects" in Constantinos Macris, "Sectes' et identité dans le monde antique. Bref tour d'horizon accompagné de quelques ébauches de réflexion," in Nicole Belayche and Simon C. Mimouni (eds.), Entre lignes de partage et territoires de passage. Les identités religieuses dans les mondes grec et romain. «Paganismes », «judaïsmes », «christianismes» (Paris-Leuven: Peeters, 2009), 23-40.

27 Plutarch, Isis and Osiris, 25, 36oF. Similarly, Diodorus Siculus, 1, 22, 7, attests to the cult of

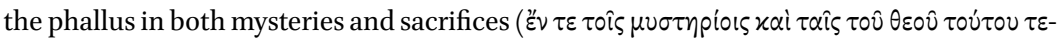

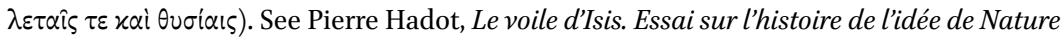
(Paris: Gallimard, 2004), 82-90. 


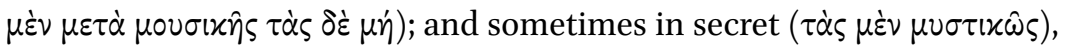
sometimes openly ( $\tau \dot{\alpha} \varsigma \delta \dot{\varepsilon} \dot{\varepsilon} \nu$ $\varphi \alpha \nu \varepsilon \rho \hat{\imath}) .28$

An inquiry into mysteries represented in images does not take into consideration all of the sequences of the festival (including procession, sacrifices, and other regular ritual practices more generally); it focuses on the concealed stage of the festival, often called initiation. Herodotus already makes this distinction when he reports the drama of Osiris performed in Sais, ${ }^{29}$ set side by side with the Greek Thesmophoriae honouring Demeter, that were permitted to married women alone:

I could say more about this, for I know the truth, but let me preserve a

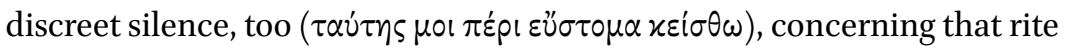

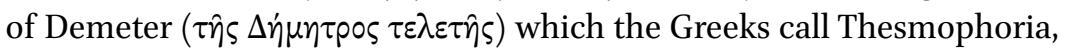

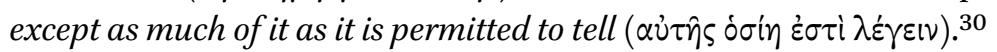

Certain stages of the festival might be revealed, yet that which is concealed is precisely delineated, as in a letter of the emperor Commodus written after he entered into the genos of the Eumolpides, which mentions $\tau \dot{\alpha} \alpha \dot{\alpha}$ ópp $\eta \alpha \tau \hat{\eta} \varsigma \kappa \alpha \tau \dot{\alpha}$ $\tau \dot{\alpha} \mu \nu \sigma \tau \hat{\eta} \rho\left\llcorner\alpha \varepsilon \lambda \varepsilon \tau \hat{\jmath} \varsigma\right.$ ("the secret rites of the initiation during the mysteries"). ${ }^{31}$

28 Strabo, 10, $3,9\left[\mathrm{C}_{467}\right]$.

29 Herodotus, 2, 171, 1: "On this lake they enact by night the story of the god's sufferings

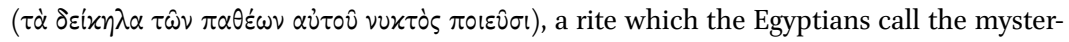

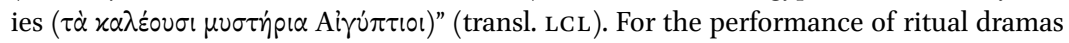
as mysteries, see Christiane Sourvinou-Inwood, "Festivals and Mysteries: Aspects of the Eleusinian Cult," in Michael B. Cosmopoulos (ed.), Greek Mysteries. The Archaeology and Ritual of Ancient Greek Secret Cults (London-New York: Routledge, 2003), 25-49; and Michael B. Cosmopoulos, Bronze Age Eleusis and the Origins of the Eleusinian Mysteries (Cambridge, MA: Cambridge University Press, 2015), 22-3, who writes of (the dromena?) "a reenactment of the sacred drama of the story of Demeter and Persephone, accompanied by music, singing, and perhaps dancing" (22). On dance and music in mysteries, see Lucian, The Dance, 15 (claiming an Orphic origin of mysteries).

30 Herodotus, 2, 171, 2 (emphasis added), quoted in support of the rule of silence by Plutarch, The obsolescence of oracles, 14, 417C. Cf. Homeric Hymn to Demeter, 479 and Plutarch, Alcibiades, 22, 5, on condemnation for parodying the Eleusinian Mysteries. For the "mystical silence" in Plutarch (On Talkativeness, 7, 505F), see Peter Van Nuffelen, "Words of Truth. Mystical Silence as a Philosophical and Rhetorical Tool in Plutarch," Hermatena 182 (2007), 9-39. See also André Motte, "Silence et secret dans les mystères d'Éleusis," in Julien Ries and Henri Limet (eds.), Les rites d'initiation (Louvain la Neuve: Centre d'Histoire des Religions, 1986).

31 IG II $^{2}$ 1110, 16-17 (= IEleusis 513; transl. James H. Oliver, Greek Constitutions of Early Roman Emperors from Inscriptions and Papyri (Philadelphia: American Philosophical Society, 1989), no. 206, 416-418. 
It comes thus as no surprise (sadly, for the historian) that "descriptions" of these mystery rituals cannot exist. Pausanias makes the point when he arrives at the sanctuary at Eleusis:

My dream forbade the description of the things within the wall of the sanctuary, and the uninitiated are of course not permitted to learn that

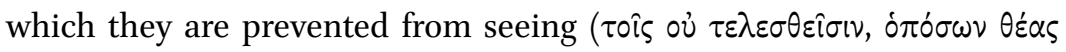

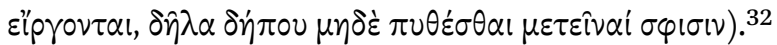

Paradoxically, Christian authors are the more informative sources at this stage; yet they must be read critically because of the biases of their polemical discourses. Even when pagan narratives come close to the mystery experience, it is but symbolically revealed, as in the last book of Apuleius' Metamorphoses (The Golden Ass), ${ }^{33}$ to say nothing here of the vexed question of "Isiac mysteries", when this literary discourse is set alongside with other kinds of evidence. ${ }^{34}$

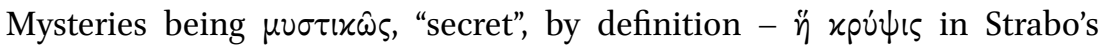
words -35 it may be worthwhile to search forvisual representation of mysteries, ${ }^{36}$ inasmuch as visual language speaks using metaphors through its own semiotic codes. And yet why would members of mystery groups have been willing to depict the ceremonies about which they kept silent? And for which viewers were they intended? And why were the images of mysteries, or rather images which scholars read as depicting mysteries, found in such diverse types of buildings, both connected or/and unconnected with cult sites, including, for instance, domestic spaces? ${ }^{37}$

32 Pausanias, 1, 38, 7; see Kevin Clinton, "Stages of Initiation in the Eleusinian and Samothracian Mysteries," in Greek Mysteries, 50-78. An anecdote in Suetonius, Augustus, 93, describes Augustus, who was initiated to the Eleusinian mysteries, holding a closed session in a trial when quaedam secretiora proponerentur.

33 Apuleius, Metamorphoses, 11, 23.

34 See the negative conclusions of Julietta Steinhauer, "Osiris Mystes und Isis Orgia - Gab es ,Mysterien' der ägyptischen Gottheiten?", in Nagel, Quack, and Witschel (eds.), Entangled Worlds, 47-78; Francesco Massa, "Le mythe fait-il les mystères? Interprétations chrétiennes des mystères égyptiens ( $\mathrm{II}^{\mathrm{e}}-\mathrm{IV}^{\mathrm{e}}$ siècles)," Revue de l'histoire des religions 235,4 (2018), 701-22; and R. Veymiers infra p. 123-68.

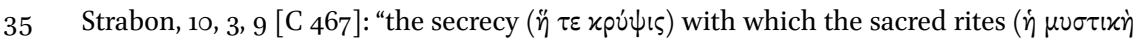

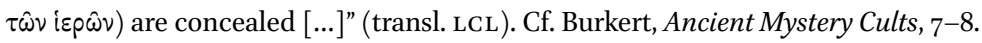

${ }_{3} 6$ The question is different to that of the role of images during the rituals of mystery cults, a hypothesis regularly put forth concerning the various scenes of the predellae's tauroctony in mithraea.

See infra n. 144 for the Pompeian so-called "House of Mysteries". 


\subsection{The Importance of Seeing in the Mystery Rites}

Thus expressed, the problem addressed in this book may sound like a challenge, yet the paradox may be only apparent. Before coming to "images" of mysteries, let us begin from a broad etymological perspective. The lexicon regularly used to express mystery-related matters is frequently connected to the act of seeing - as the Eleusinian title hiero-phantes suggests -38 and to things or images that are seen, ${ }^{39}$ and forbidden to be revealed to the non-initiates:

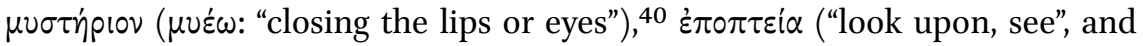

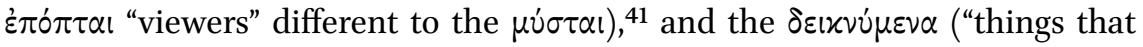
are shown"), the sacred objects shown to the initiates in Eleusis. ${ }^{42}$ All these "things shown" might have inspired visual representations. A similar context of viewing is expressed in the light and sudden enlightment ( $(2 \lambda \lambda \alpha \mu \psi(\varsigma)$, which closed the initiatory experience. Many Eleusinian inscriptions use the formula ispà $\varphi \alpha i v \varepsilon v$, related etymologically to the hierophantes who "displayed the

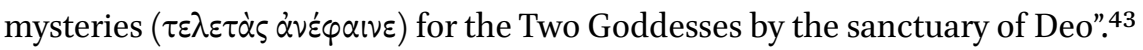

38 Cf. Karl Kerényi, Eleusis: An Archetypal Image of Mother and Daughter (London: Routledge, 1967), for an interpretation of the $\mu$ únбıs as an experience of "seeing the unseen". See also Dario Sabbatucci, Saggio sul misticismo Greco (Rome: Edizioni dell'Ateneo, 1965), 147 ("luce, visione dell'alterità [...], illuminazione [...], salvezza futura", at Eleusis). Marlis Arnhold, Harry O. Maier and Jörg Rüpke (eds.), Seeing the God. Image, Space, Performance, and Vision in the Religion of the Roman Empire (Tübingen: Mohr Siebeck, 2018), do not consider mystery cults.

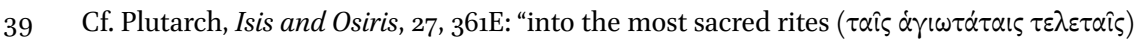

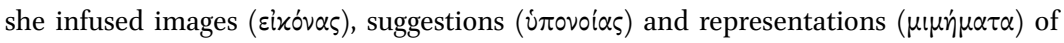
her experiences at that time ( $\left.\tau \hat{\omega} \nu \tau \delta^{\prime} \tau \varepsilon \pi \alpha \theta \eta \mu \dot{\alpha} \tau \omega \nu\right)$ ", transl. LCL.

40 Cf. Souda s.v. $\mu \nu \sigma \tau \dot{p} \rho \alpha^{\alpha}$. For $\mu \nu \sigma \tau \dot{p} \rho 10 v$ on the singular, IStratonikeia $23,3-4$ and 30, 2-3, and $I G \mathrm{II}^{2} 3661=$ IEleusis 646 (ca. $235 \mathrm{CE}$ ). See Silvia Montiglio, Silence in the Land of the Logos (Princeton, NJ: Princeton University Press, 2000), 23-31 ("Closing One's Lips, Closing One's Eyes: Silence in the Initiation into the Eleusinian Mysteries").

41 Clinton, "Stages of Initiation," 5 o.

42 Cf. Andocides, On the Mysteries, 31: "at the same time you are here as initiates who have

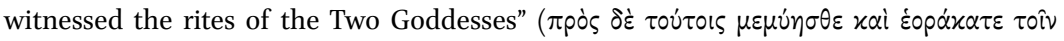

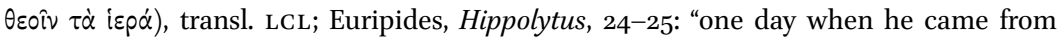
Pittheus' house to the land of Pandion to see and celebrate the holy mysteries ( $\sigma \varepsilon \mu \nu \omega \hat{\omega} \nu$

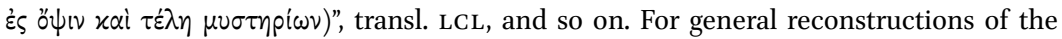
Eleusinian ceremonies, see Paul Foucart, Les mystères d'Éleusis (Paris: Picard, 1914), 355456, and Georges Mylonas, Eleusis and the Eleusinian Mysteries (Princeton, NJ: Princeton University Press, 1961); recently Cosmopoulos, Bronze Age Eleusis, 17-24 (with a critical reading of entheogenic theories) and Bremmer, Initiation, 7-16.

$43 I G \mathrm{II}^{2} 3764$, in 217/218; see also $3661,3-4$ (end of the second-beginning of the third century): Glaukos "displayed to all mankind the light-bringing rites of Deo for nine years" (oppr $\alpha$

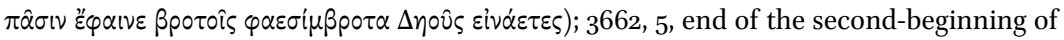
the third century. 
Aristotle (possibly paraphrased more than quoted by Synesius of Cyrene $)^{44}$ put a sharp distinction between seeing and hearing that, unlike Plato, he equated to the distinction between a dialectical process of knowledge (hearing) and an immediate and experiential one (seeing):

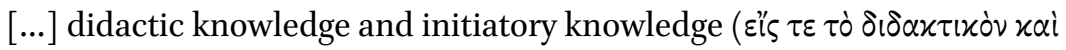
$\tau \dot{0} \tau \varepsilon \lambda \varepsilon \sigma \tau(x o ́ v)$ : the first comes to men through hearing ( $\dot{\alpha} x \circ \hat{\eta})$, and the

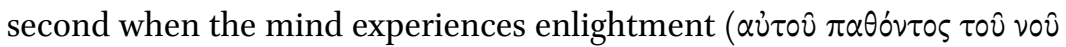

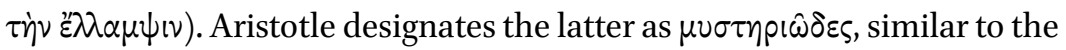
Eleusinian Mysteries. In these mysteries indeed, the one who is initiated

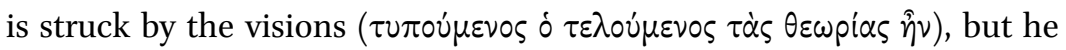

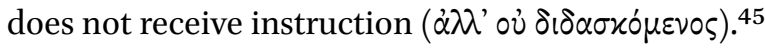

Greek authors who rationalized the characteristics of initiation or mystery experience related it to a form of knowledge resulting from a particular process of learning, produced by a sudden and immediate experience (exaiphnes). Plato called it "telestic" 46 or "epoptic", drawing on the terminology of the

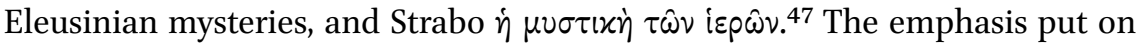
sensations and perceptions - expressed by the Aristotle's formula oủ $\mu \alpha \theta \varepsilon i v$ $[\ldots] \dot{\alpha} \lambda \lambda \dot{\alpha} \pi \alpha \theta \varepsilon \hat{\imath}$, transmitted by Synesius of Cyrene -48 explains why neurocognitivist theories may be applicable to the study of the ancient mysteries. ${ }^{49}$ We shall later return to this question.

44 The term $\mu \nu \sigma \tau \eta \rho i \omega ́ \delta$ is not attested in Greek literature before Plutarch. Olof Gigon, Aristotelis Opera, vol. III, Librorum Deperditorum Fragmenta (Berlin-New York: De Gruyter, 1987), lists the passage among the dubia.

45 Aristotle, Peri philosophias, fr. 15b, Ross (quoted by Psellus, Commentary on Iohannes Climachus); see Jeanne Croissant, Aristote et les mystères (Liège-Paris: Faculté de Philosophie et Lettres-Droz, 1932), 145-6. See Alberto Bernabé, "Aristotle and the Mysteries," in Martin-Velasco and Garcia Blanco (eds.) Greek Philosophy and Mystery Cults, 27-42; Yulia Ustinova, Divine Mania: Alteration of Consciousness in Ancient Greece (Oxford: Oxford University Press, 2017), 135-6.

46 Plato, Phaedrus, 265b.

47 Strabo, 10, 3, 9 [C 467].

48 Synesius of Cyrene, Dion, 8, 5-8 = Aristotle, Peri philosophias, fr. 15, Ross: $\tau$ -

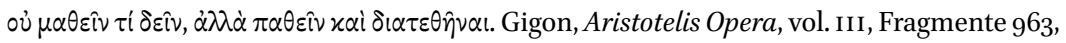
p. 829 , lists the passage among the dubia.

49 E.g. Yulia Ustinova, "To Live in Joy and Die with Hope: Experiential Aspects of Ancient Greek Mystery Rites," Bulletin of the Institute of Classical Studies 56, 2 (2013), 105-23; Olympia Panagiotidou and Roger Beck, The Roman Mithras Cult: A Cognitive Approach. 
Mysteries, and particularly the stage of initiation that uses the logic of pars pro toto, ${ }^{50}$ are deeply related to vision(s) that images of mysteries may attempt to express, ${ }^{51}$ as in the case of the adornment of Isis' initiates, which, according to Plutarch, represents their sacred knowledge:

as though within a casket ( $\omega \sigma \pi \varepsilon \rho \dot{\varepsilon} \nu$ xi $\sigma \tau \eta)[\ldots]$ they cloak them with secrecy, thus giving intimations, some dark and shadowy ( $\tau \dot{\alpha} \mu \dot{\varepsilon} \nu \mu \dot{\varepsilon} \lambda \alpha \nu \alpha$

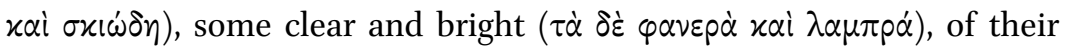
conceptions of the gods, intimations of the same sort as are clearly evi-

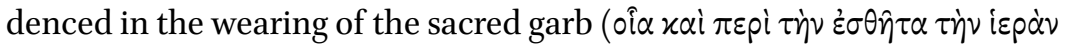
$\dot{\alpha} \pi \circ \varphi \alpha(v \varepsilon \tau \alpha l) .52$

The frescoes of the mithraeum of Santa Maria Capua Vetere, which are currently interpreted as depicting an initiation, play on these processes, at once symbolic and (at times) experienced: juxtapositions of the candidate for initiation nude vs. already-initiated ritual agents dressed; of the candidate kneeling and lying down vs. the ritual agents standing; of the candidate with eyes covered vs. eyes uncovered, thus of blindness vs. illumination..$^{53}$ Generally they are read with the guidance of the famous fragment of Plutarch on the Eleusinian "Great Mysteries":

The soul suffers as do those who have been initiated into the great

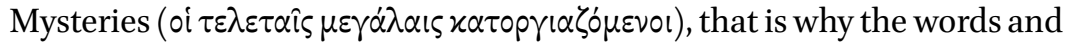
the actions of dying ( $\tau \varepsilon \lambda \varepsilon v \tau \hat{\alpha} \nu)$ and performing the rituals ( $\tau \varepsilon \lambda \varepsilon \hat{i} \sigma \theta \alpha \mathrm{l})$ resemble each other. At first there were wanderings and exhausting walks,

$5^{\circ} \quad$ Using the definition of Ugo Bianchi, "Initiation, mystère, gnose," in Claas J. Bleeker (ed.), Initiation, Contributions to the Theme of the Study-Conference of the I.A.H.R., Strasbourg, September 17th to 22nd 1964 (Leiden: Brill, 1965), 154-71, esp. 155: "nous entendons par 'initiation' l'accession rituelle d'un individu ou d'un groupe homogène dans un état, ou plus spécifiquement, dans un corps sacralement qualifié et religieusement 'autre'”.

51 For an organic link between mysteries and allegory, see Demetrius of Phaleron, On style,

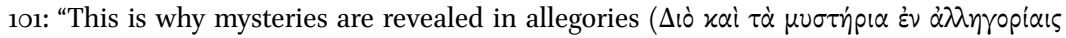

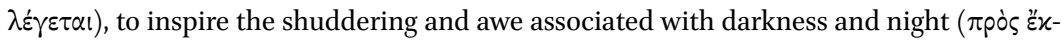

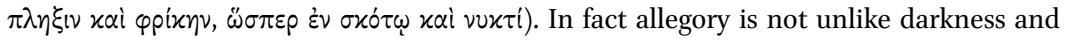

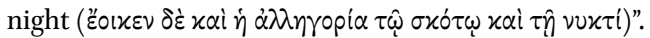

52 Plutarch, Isis and Osiris, 3, 352 B (transl. LCL slightly modified).

53 Marteen J. Vermaseren, Mithriaca I. The Mithraeum at S. Maria Capua Vetere (Leiden: Brill, 1971). Yet it is reexamined by Richard Gordon, "The Mithraic Body: The Example of the Capua Mithraeum", in Giovanni Casadio and Patricia A. Johnson (eds.), Mystic Cults in Magna Grecia (Austin: University of Texas Press, 2009), 290-313: "the panels do not "depict" rituals in any direct or uncomplicated sense". 


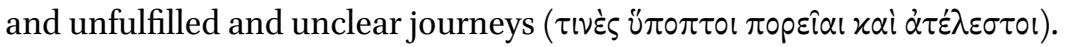

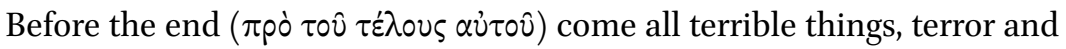

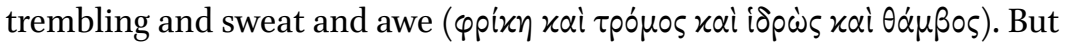
after this, a marvelous light ( $\varphi \hat{\omega} \varsigma \tau \iota \theta \alpha \mu \dot{\alpha} \sigma i o v)$ appears, and pure spaces and meadows receive [scil. the initiate], with voices and choirs and the

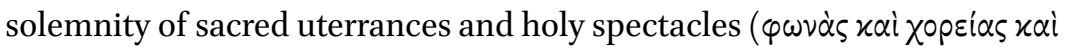

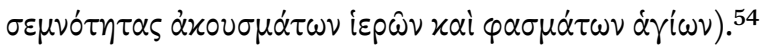

\section{2 The Lexicon, a Dead End?}

There is no common definition and list of "mystery cults" among scholars, with the exception of a phenomenological model set out in Burkert's reference work. ${ }^{55}$ Yet ancient authors, from the Hellenistic times onwards, considered them to be one of the two types of experience of the divine. The demand for secrecy, already noted ${ }^{56}$ provides us with the first explanation for this. It invites us to, at least, categorize as "mystery" all restricted and concealed ceremonies, whatever their content. ${ }^{57}$ The same authors use polysemic terms for these ritual forms, like $\mu \nu \sigma \tau \eta \dot{p}\llcorner\alpha, \tau \varepsilon \lambda \varepsilon \tau \alpha i$, öpүı in Greek, mysteria, initia, sacra in Latin. ${ }^{58}$ In Greek (which has more numerous attestations), ${ }^{59}$ they point to various ritual experiences, from initiatory rites built on the Eleusinian model to any evocation of a close experience with the deities and their powers - for instance Aelius Aristides reporting his oneiric relationship with his beloved

54 Plutarch, De anima (fr. 178 Sandbach), ap. Stobaeus, 4, 52, 49; a similar mix of fear and anguish $\left(\dot{\alpha} \gamma \omega v^{i} \alpha\right)$ and joy and happiness (i்ovn̂) is found in Aelius Aristides, Orations, 5o, 7 (Sacred Tales, 4). For Eleusis see Foucart, Mystères, 393; Burkert, Ancient Mystery Cults, 73-5. See also infra p. 22.

55 Burkert, Ancient Mystery Cults, 4. See before Arthur D. Nock, "Hellenistic Mysteries and Christian Sacraments," Mnemosyne 5 (1952), 177-213, reed. Essays on Religion and the Ancient World, 2 (Oxford: Clarendon Press, 1972), 791-820: "a persistent unity which transcended varieties of meaning" (797).

56 It opens Bremmer's list of nine "general characteristics": Bremmer, Initiation, 12.

57 For instance, in Ephesus, the $\mu \nu \sigma \tau$ ' $\rho 1 \alpha$ of Artemis are delineated only by a specific group of ritual agents who look like they are involved in regular ritual gestures: see Nicole Belayche, "Les hiérophantes marqueurs des « mystères »? Le cas de l'Artémis éphésienne," Mètis N.S. 14 (2016), 49-74.

$5^{8}$ For Latin, see Francesco Massa and Damien Nelis (eds.), Mystery Cults in Latin Texts, Mnemosyne (forthcoming).

59 A recent English-language list, produced after a 1934-1939 Dutch repertoire, is found in Feyo L. Schuddeboom, Greek Religious Terminology, Telete \& Orgia. A Revised and Expanded English Edition of the Studies by Zijderveld and Van der Burg (Leiden-Boston: Brill, 2009). 
Asclepius. ${ }^{60}$ Thus, starting from this vague definition of the "mysteries" risks reaching a dead end.

How can such diverse meanings of $\mu \nu \sigma \tau \eta \dot{p}\left\llcorner\alpha\right.$ or $\tau \varepsilon \lambda \varepsilon \tau \alpha \alpha^{\prime}$ be harmonized? In the Classical Athenian festive calendar, $\tau \dot{\alpha} \mu \nu \sigma \tau \dot{p} \rho 1 \alpha$ was the name of the Boedromion (September) panegyris that began at Athens and took place at the Eleusinian sanctuary, after a first and lesser feast in spring at Agra. Thus, in Greek minds, long afterwards, $\tau \dot{\alpha} \mu \nu \sigma \tau \dot{p} \rho \ltimes \alpha$ designated the Eleusinian rites offered to "the Two Goddesses", Demeter and Kore. ${ }^{61}$ Yet the second-century grammarian Aelius Herodianus indicates that the term was not restricted to these peculiar deities and event. In his treatise On orthography, he gives an etymological explanation of the Arrhephoria dedicated to Athena Polias: "It

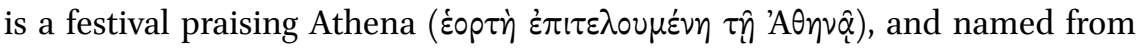
the expression 'to carry' ( $\varphi \varepsilon \dot{\rho} \varepsilon v)$ the unspeakable and the mysteries ( $\pi \alpha \rho \dot{\alpha} \tau \dot{~}$

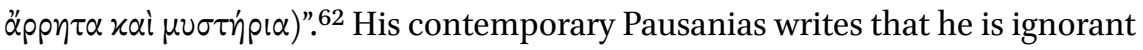
of what is carried during this festival, though he makes no other reference to mysteries. The two arrhephoroi were brought nightly ( $\dot{\varepsilon} v v 0 x \tau i)$ from the temple of Athena on the Acropolis to the sanctuary of the so-called Aphrodite in the Gardens, where is a natural subterranean descent ( $x \dot{\alpha} \theta 0 \delta 0$ s i $\pi \dot{\gamma} \gamma \alpha 10 \varsigma)$. They had "on their head that which the priestess of Athena gives them to carry ( $\dot{\varepsilon} \pi \dot{i} \tau \dot{\alpha} \varsigma$

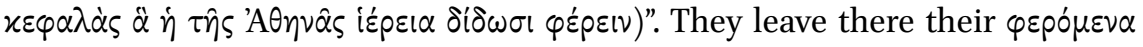
and return with what had been carried the year before. Neither the priestess

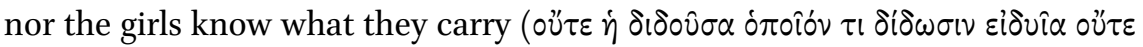

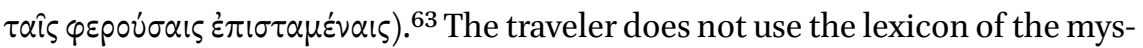
teries, like Herodianus; yet the nocturnal timing and the enigmatic $\varphi \varepsilon \rho o ́ \mu \varepsilon v \alpha$ explain Herodianus's reading in terms of the mysteries. ${ }^{64}$

6o Aelius Aristides, Orations, 48, 32 (Sacred Tales, 2); see also 49, 46 and 48 (Sacred Tales, 3). An extensive use of mysteria is made by Clement of Alexandria to report the regular practices of the traditional cults: Francesco Massa, "La notion de 'mystères' au II ${ }^{\mathrm{e}}$ siècle de notre ère: regards païens et Christian turn," Mètis N.s. 14 (2016), 109-32.

61 See Paolo Scarpi, Le religioni dei misteri, I. Eleusi, dionisismo, orfismo (Milan: Mondadori, 2002), XI-XXVII.

62 Herodian, On Orthography, 3, 2 (479).

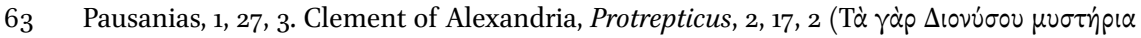
$\tau \dot{\varepsilon} \lambda \varepsilon \circ \nu \alpha \dot{\alpha} \pi \dot{\alpha} \nu \rho \omega \pi \alpha)$, later quoted by Eusebius of Caesarea (Preparation for the Gospel, 2, 3, 23), connects the Arrhetophoria with Dionysiac mysteries in the Eleusinian context. On Clement and Eusebius, see Massa, "La notion de 'mystères'," 126.

64 For recent interpretations of the festival as an "initiation rite", see Fritz Graf, "Initiation. A Concept with a Troubled History," in David B. Dodd and Christopher A. Faraone (eds.), Initiation in Ancient Greek Rituals and Narratives. New Critical Perspectives (London: Routledge, 2003), 3-24, esp. 12-4. 
The word $\tau \varepsilon \lambda \varepsilon \tau \eta \dot{~ i s ~ m o r e ~ c o m m o n . ~ I t ~ c o v e r s ~ s u c h ~ a ~ l a r g e ~ r a n g e ~ o f ~ m e a n i n g s ~}$ that it may express any kind of ritual act or ceremony, down to the late lexica of the Christian times. ${ }^{65}$ And yet, already in the Classical period, the initiatory or mystery sense of $\tau \varepsilon \lambda \varepsilon \tau \dot{\eta}$ was associated with two specific cults: those of Eleusis and Dionysos. ${ }^{66} \mathrm{~T} \varepsilon \lambda \varepsilon \tau \eta^{\prime}$ is also frequently used in inscriptions reporting the ceremonies connected with entering a priesthood. ${ }^{67}$ Besides the semantic field of achievement ( $\tau \varepsilon \lambda \varepsilon i v)$, this might colour the meaning of $\tau \varepsilon \lambda \varepsilon \tau \dot{\eta}$ with a context of the transmission ( $\pi \alpha p \alpha \dot{\delta} \delta \sigma / \varsigma)$ of ritual or religious knowledge: in the second century, Athenaeus defined $\tau \varepsilon \lambda \varepsilon \tau \alpha i$ as "ceremonies with a secret

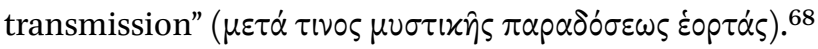

The large semantic range of $\tau \varepsilon \lambda \varepsilon \tau \eta^{\prime}$ according to the various types of evidence, and the variability of the lexicon connected to "mysteries", are confirmed by the related terms in Julius Pollux' Onomasticon. Written under the reign of Commodus (180-192) by a professor of rhetoric at Athens, the Onomasticon is a ten-book lexicon of Attic synonyms, compiled according to subject matter. ${ }^{69}$

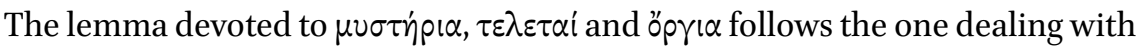

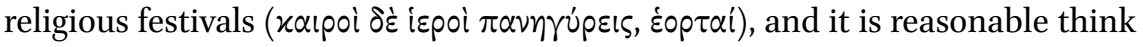
of it as a continuation this previous discussion. The lemma gives a list of terms (nouns, verbs, adjectives) connected to mystery rites:

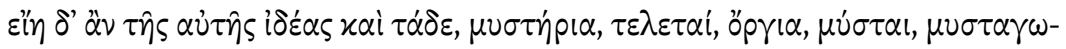

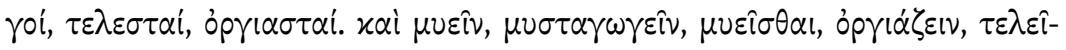

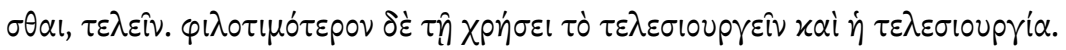

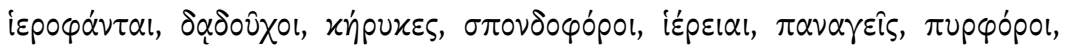

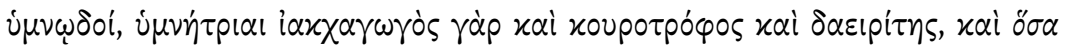

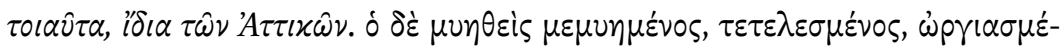

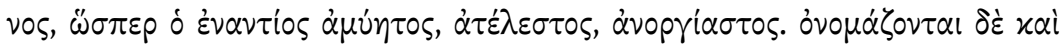

65 See Sfameni Gasparro, Misteri e teologie, 99-117 ("Ancore sul termine TE $\Lambda$ ETH. Osservazioni storico-religiose").

66 Herodotus, 4, 79; Diodorus Siculus, 1, 22, 6-7.

67 E.g. at Cos, Mario Segre, Iscrizioni di Cos (Rome: L'Erma di Bretschneider, 2007), 144, ll. $12-$ 14, for the priesthood of Adrasteia and Nemesis; see also that of Zeus Polieus, Stéphanie Paul, "Roles of Civic Priests in Hellenistic Cos," in Marietta Horster and Anja Klöckner (eds.), Cities and Priests. Cult Personnel in Asia Minor and the Aegean Islands from the Hellenistic to the Imperial Period (Berlin-Boston: De Gruyter, 2013), 247-78, esp. 254-6.

68 Athenaeus, Deipnosophists, 2, 12, 8 (4od). In Latin, the verb tradere is frequently used in these contexts; see Apuleius, Metamorphoses, 11, 29 and Nicole Belayche, "Les dévots latinophones de Mithra disaient-ils leurs mystères - et si oui, comment?", in Massa and Nelis (eds.), Mystery Cults in Latin Texts.

69 See Cinzia Bearzot, Franca Landucci, and Giuseppe Zecchini (eds.), L'Onomasticon di Giulio Polluce. Tra lessicografia e antiquaria (Milan: Vita e Pensiero, 2007). 


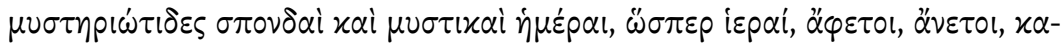

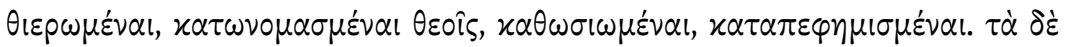

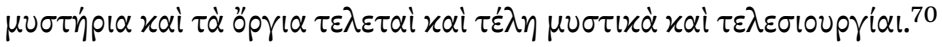

In the first sentence, three terms designate ceremonies ( $\mu \nu \sigma \tau \eta^{\prime} \rho 1 \alpha, \tau \varepsilon \lambda \varepsilon \tau \alpha i$ and oppr $\alpha$ ); one term refers to the initiates $(\mu \dot{v} \sigma \tau \alpha)$ ), and three others designate

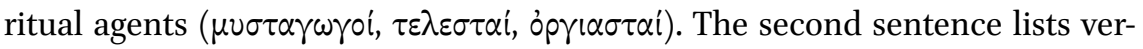
bal forms corresponding to the aforementioned nouns. Lastly, another list of ritual agents is given, all in their plural forms: hierophants and torch-bearers are linked to Eleusis, yet the remaining experts are not specific to the mysteries

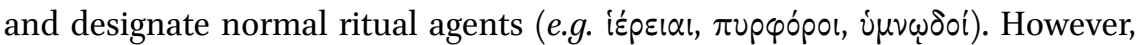
Pollux mentions three functions in the singular, which he connects to an Attic

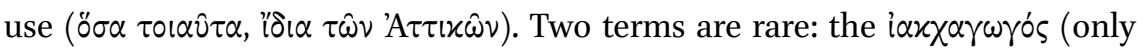
attested in inscriptions of the imperial period), ${ }^{71}$ and the $\delta \alpha \varepsilon i p i t \eta \varsigma$, "the one who knows" (a hapax), ${ }^{72}$ an expression that might be associated with the Eleusinian mysteries. The third, xoupotpóyos, is an epithet. Lastly, Pollux lists

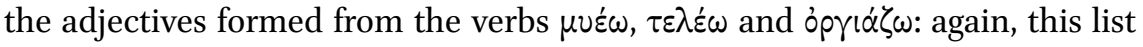

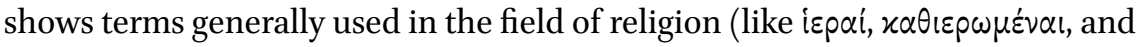
so on). This entry of the lexicon demonstrates the fluidity of the vocabulary of "mysteries" in the second century. The Attic and Eleusinian contexts are obvious, even though Pollux does not name any specific mystery cult. Such an overlap between mystery terminology and the Eleusinian mysteries is a convincing testimony to the pervasiveness of the Eleusinian model in the representations of mystery cults in the Imperial age.

From the Hellenistic period onwards, $\tau \varepsilon \lambda \varepsilon \tau \eta \dot{~ i s ~ u s e d ~ l o o s e l y ~ t o ~ r e f e r ~ t o ~ r e l i-~}$ gious festivals with no connection to Eleusis, and the trend increases up until the second century CE. Far removed from the common image of mystery cults, at the border of oracular answer and revelation, Aelius Aristides refers to an incubatory vision of ladders leading to the world ruled by Sarapis, as $\tau \varepsilon \lambda \varepsilon \tau \eta \dot{:}$

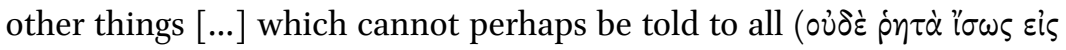
$\ddot{\alpha} \pi \alpha \nu \tau \alpha \varsigma)$, with the result that I gladly beheld that the tokens of Asclepios

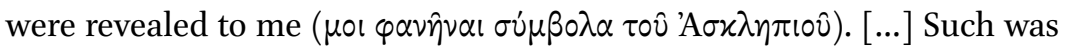
the initiation ( $\tau 01 \alpha \hat{v} \tau \alpha \hat{\eta} \nu \tau \dot{\alpha} \tau \hat{\eta} \varsigma \tau \varepsilon \lambda \varepsilon \tau \hat{\eta} \varsigma) .{ }^{73}$

70 Pollux, Onomasticon, 1, 35-36 (we underline).

$71 \quad I G \mathrm{II}^{2}, 1092 \mathrm{~B} 31$ (after $131 \mathrm{CE}$ ); 3733 (in 126-127) and 4772.

72 This may be a ritual agent linked with Persephone $\Delta \dot{\alpha} \varepsilon i \rho \alpha$. On the divine figure called $\Delta \dot{\alpha} \varepsilon i p \alpha$, see e.g. IG $\mathrm{II}^{2} 1496$.

73 Aelius Aristides, Orations, 49, 48 (Sacred tales, 3, transl. C. A. Behr). See Alexia PetsalisDiomidis, Truly Beyond Wonders: Aelius Aristides and the Cult of Asklepios (Oxford- 
The use of mystery terminology is enhanced when it is used to designate the liturgy and ritual practices of Jesus' followers, and becomes a core element in the development of Christian vocabulary from the end of the second century on. In Christian texts, $\mu \nu \sigma \tau \eta^{\prime} \rho \alpha$ and $\tau \varepsilon \lambda \varepsilon \tau \alpha i$ designate both the totality of Christian doctrines, and ritual practices such as baptism and the Eucharist. ${ }^{74}$ Being one of the two major types of religious experiences in Antiquity, mysteries played a formative role in the relations between pagans and Christians, as an extremely rich historiography has already underlined. ${ }^{75}$ Moreover, after the end of the second century, Christian authors constructed a new category of "mysteries" in order to distinguish true mysteries (the Christian orthodoxy) from false mysteries (paganism and heresies). ${ }^{76}$

New-York: Oxford University Press, 2010), 234-8, who discusses elite worshippers who practise incubation and receive the divine $\chi \alpha \dot{p} ı \varsigma$, thus justifying the metaphorical use of "initiation". A similar use of "mystery" with explicit Eleusinian references is already found in Philo, On the Cherubim, 49: "for under Moses, the friend of God, I was initiated in the

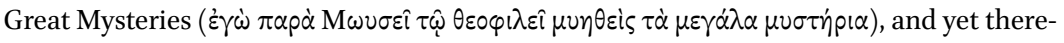
after when I came to see the prophet Jeremiah and to recognize that he was not only

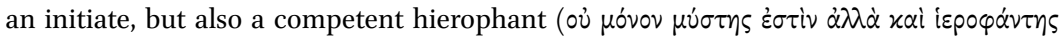
ixavós), I did not shrink from going to his school", transl. LCL.

74 Particularly from the end of the fourth century, Christian liturgy was organized around what modern scholarship calls arcana disciplina, that excluded the non-baptized from certain teachings and rituals of the Christian community; see Guy G. Stroumsa, "Paradosis. Traditions ésotériques dans le christianisme des premiers siècles," in Id., Savoir et salut. Traditions juives et tentations dualistes dans le christianisme ancien (Paris: Cerf, 1992), 127-43, and Michel-Yves Perrin, "Arcana mysteria ou ce que cache la religion. De certaines pratiques de l'arcane dans le christianisme antique," in Matthias Riedl and Tilo Schabert (eds.), Religionen - Die Religiöse Erfahrung (Würzburg: Königshausen \& Neumann, 2008), 119-42. On the mystery vocabulary in Christian texts, see J. D. B. Hamilton, "The Church and the Language of Mystery. The First Four Centuries," Ephemerides Theologicae Lovanienses 53, 4 (1977), 479-94; Christoph Riedweg, Mysterienterminologie bei Platon, Philon und Klemens von Alexandrien (Berlin-New York: De Gruyter, 1987); Francesco Massa, "Luci e misteri a Costantinopoli. Concorrenze religiose nell'orazione XXXIX di Gregorio di Nazianzo," Humanitas 75, 5-6 (2017), 779-9o and Id., "Les mystères chez Eusèbe de Césarée: entre débat philosophique et polémique religieuse," in Alain Le Boulluec, Luciana G. Soares Santoprete, and Andrei Timotin (eds.), Exégèse, révélation et formation des dogmes dans l'Antiquité tardive (Paris: Institut des Études Augustiniennes, 2020), 173-95. See also Robert Turcan, "Les pères ont-ils menti sur les mystères païens?," in Les pères de l'Église au XX $X^{e}$ siècle. Histoire - Littérature - Théologie. L'aventure des Sources chrétiennes (Paris: Cerf, 1997), 35-56.

75 Jonathan Z. Smith, Drudgery Divine: On the Comparison of Early Christianities and the Religion of Late Antiquity (Chicago: University of Chicago Press, 199o) and Bremmer, Initiation, 142-54.

76 On Christian use of mysteries in heresiological discourse, see Alain Le Boulluec, "Discours hérésiologique et dénominations des 'sectes', in Nicole Belayche and Simon C. Mimouni (eds.), Les communautés religieuses dans le monde gréco-romain. Essais de définition 


\section{Historiographical Models from the Religionsgeschichtliche Schule to Walter Burket and Beyond}

Such a wide range of uses of the same lexicon may explain why the mystery cults of the Greek and Roman periods have prompted such diverse hermeneutic tools and scholarly discussions on the notions of mystery/initiation/ mysticism from the twentieth century up until today. In the second half of the nineteenth century, a new trend of research on the "origins" of Christianity opened the way for an in-depth study on "mystery religions". The so-called German Religionsgeschichtliche Schule, a group of somewhat heterogeneous scholars, developed an analysis of Christianity in the context of the other religions of its time. ${ }^{77}$ Though their conclusions were diverse, their common goal was to identify and highlight both the Judaeo-Hellenistic and Graeco-Roman roots of Christianity. In their perspective, the turning point was provided by the writings of Paul, who, under the influence of the Graeco-Roman mystery religions, turned Christianity into a similar "religion of salvation". The issue was no longer to link the origins of Christianity to large-scale historical developments, ${ }^{78}$ but to propose a reconstruction of the specific historical landscape within which the new religion emerged, and to retrace the connections that linked it with other religious forms of the Roman Empire. In order to tackle these questions, it was necessary to deepen knowledge of the features

(Turnhout: Brepols, 2003), 107-22; Philippe Borgeaud, "Mystères et interférences. De Jan Bremmer aux Naassènes," Mètis N.s. 14 (2016), 95-108; Francesco Massa (ed.), Mystery Cults and Heresies in the Roman Empire: Polemics, Identities, and Interactions, Religion in the Roman Empire 4, 2 (2018), 275-375.

77 Although this is the current expression used to name this intellectual movement, it is not proper to call it a "school"; it would be more correct to talk about a "religionsgeschichtliche method which is more or less radically employed": see Ernst Troeltsch, "The Dogmatics of the Religionsgeschichtliche Schule," The American Journal of Theology, 17, 1 (1913), 1-21, esp. 3. On this group of theologians see Carsten Colpe, Die Religionsgeschichtliche Schule. Darstellung und Kritik ihres Bildes vom gnostischen Erlösermythos, (Göttingen: Vandenhoeck \& Ruprecht, 1961); Volkhard Krech, Wissenschaft und Religion: Studien zur Geschichte der Religionsforschung in Deutschland 1871 bis 1933 (Tübingen: Mohr Siebeck, 2002), 124-6; and Martina Jenssen, Stanley F. Jones, and Jürgen Wehnert (eds.), Frühes Christentum und Religionsgeschichtliche Schule: Festschrift zum 65. Geburtstag von Gerd Lüdemann (Göttingen: Vandenhoeck \& Ruprecht, 2011).

78 Simon C. Mimouni underlines how in the 18 oos the issue was still embedded "dans le cadre plus général de la question de l'origine du monde, abordée alors de manière plus empirique que scientifique": "Les origines du christianisme aux XIX ${ }^{\text {ème }}$ et XX ${ }^{\text {ème }}$ siècles en France. Question d'épistémologie et de méthodologie," in Mohammad A. Amir-Moezzi and John Scheid (eds.), L'Orient dans l'histoire religieuse de l'Europe. L'invention des origines (Turnhout: Brepols, 2000), 101-20, esp. 101. 
and diffusion of pagan religions that could have played a decisive role in the formation of Christianity, namely in the first century CE.

In 1905, Franz Cumont developed a concept of mystery cults that remains in use, ${ }^{79}$ despite decisive re-examinations. ${ }^{80}$ Cumont's construction of "oriental religions" identified "mystery" as their common core. The great Belgian scholar argued that all of their deities shared the same features, belonging to a coherent religious category, and he emphasized the "oriental" characteristics of these deities: their cosmic power to save the humans, and the privileged relationship with them for those who could access special revelations through initiation, and who in the end enjoyed a new life, hic et post mortem, that protected them. ${ }^{81}$ He developed a mystical understanding of the "mystery religions" which was later to be deconstructed. From the 1970's on, we see the syntagm "mystery cults" replacing "mystery religions". The new designation aimed at underlining both the specificity of ritual acts compared to the regular religious activities, and the embeddedness of mystery cults within traditional Graeco-Roman religions. 1987 marks a turning point in the historiography of ancient mysteries. Ancient Mystery Cults, the published form of a series of lectures Walter Burkert gave at Harvard, put a definitive end to the long-standing hermeneutic model of "mystery religions". Burkert denounced three ideas that were hallmarks of the Cumontian reconstruction:

a. The idea that mysteries were a feature of Late Antiquity, dating at the earliest to the imperial period, and thus revealed a religious evolution of Graeco-Roman paganism;

b. The idea that mysteries were "Oriental in origin, style, and spirit", following the work of Cumont and Reitzenstein; ${ }^{82}$

c. The idea that mystery religions were "spiritual"; in Burkert's words that "they are indicative of a basic change in religious attitude, one that

79 Reflections on this legacy by Jaime Alvar, Romanising Oriental Gods: Myth, Salvation and Ethics in the Cults of Cybele, Isis and Mithras, transl. and ed. by Richard Gordon (Leiden-Boston: Brill, 2008), 6-14; this legacy can be seen in e.g. Martin-Velasco and Garcia Blanco (eds.), Greek Philosophy and Mystery Cults.

80 Corinne Bonnet, Jörg Rüpke, and Paolo Scarpi (eds.), Religions orientales - Culti misterici. Neuen Perspektiven - Nouvelles perspectives - Prospettive nuove (Stuttgart: Franz Steiner, 2006).

81 Cumont, Les religions orientales, 44-67. This was still the main perspective of the conference held in Rome in 1979, Ugo Bianchi and Maarten J. Vermaseren (eds.), La soteriologia dei culti orientali nell'Impero Romano. Colloquio internazionale Roma 1979 (Leiden: Brill, 1982), though many contributions concluded with a conception of mundane salvation.

82 Cf. Cumont, Les religions orientales, and Richard Reitzenstein, Die Hellenistischen Mysterienreligionen, nach ihren Grundgedanken und Wirkungen (Leipzig: Teubner, 1927). 
transcends the realistic and practical outlook of the pagan in search for higher spirituality". ${ }^{3}$

To a lesser extent, Burkert's critique also tackled Arthur D. Nock's ideas, ${ }^{84}$ though the English scholar had already made a clear distinction between conversion and initiation ${ }^{85}$ and had abandoned the genealogical model of a passage from paganism to Christianity.

However groundbreaking Burkert's analysis was, a close reading of his Introduction demonstrates the extent to which he was still embedded within the traditional historiographical models. Fundamentally Burkert follows Cumont when he states:

What is attempted with this approach could be called a comparative phenomenology of ancient mysteries. For reasons of economy the following inquiries will be restricted to five of these: the mysteries of Eleusis, the Dionysiac or Bacchic mysteries, the mysteries of Meter, those of Isis, and those of Mithra. There were others as well, some of them quite prominent, but these five variations will suffice to indicate the range of differences as well as the constants in diversity. This approach may be criticized as ahistorical. What is covered is a period of about a thousand years, and shifts, changes, and revolutions were constantly occurring at the social, political, and intellectual levels. ${ }^{86}$

This assertion raises at least two questions. The first is chronological. Burkert is fully aware of it (an "ahistorical" "approach"), yet he chooses to bypass it for the sake of a phenomenological perspective. Consequently, he discusses mystery "religions" despite having correctly identified peculiar ritual forms ("cults"). The second question concerns the cults he has listed. Burkert brings

83 Burkert, Ancient Mystery Cults, 3. Burkert's view has been recently confirmed by, to name one among many, Theodora S. F. Jim, "Salvation' (Soteria) and Ancient Mystery Cults," Archiv für Religionsgeschichte 18-19 (2017), 255-81, who demonstrates that there is no evidence for after-life expectations when soteria occurs in mystery contexts.

84 See supra n. 55 .

85 Arthur D. Nock, Conversion: The Old and the New in Religion from Alexander the Great to Augustine of Hippo (Oxford: Oxford University Press, 1933). For a revisitation with emphasis on group affiliation, see Birgitte S. Bøgh (ed.), Conversion and Initiation in Antiquity: Shifting Identities, Creating Change (Frankfurt-New York: P. Lang, 2014), and Ead., "Beyond Nock: From Adhesion to Conversion in the Mystery Cults", History of Religions 54 (2015), 26o-87. For a useful reflection of the "state of the art" on the concept of initiation, see Graf, "Initiation".

86 Burkert, Ancient Mystery Cults, 4, emphasis added. 
together "mysteries" that are attested historically (Eleusis and Mithras), ${ }^{87}$ and others that are either poorly documented in the Roman period (the Mother) ${ }^{88}$ or highly speculative (Dionysos, Isis). ${ }^{89}$ In truth, Burkert's list corresponds to that of Cumont, who took the "oriental" deities to be, by definition, connected to the mysteries: "toutes les dévotions venues du Levant ont pris la forme de mystères". ${ }^{90}$ Moreover Burkert's introduction reveals a second model, in the wake of his German philological habitus:

But for those who took part in the chances and risks of individual freedom that had come into existence in the Hellenic world, the mysteries may have been a decisive "invention". ${ }^{1}$

What is at play here is the paradigm of German Classicism of the first half of the twentieth century, and namely the model of the "third humanism" as coined by Werner Jaeger in Paideia. ${ }^{92}$ Burkert's mysteries appear to participate in the discourse of Greek particularity and the idea of ancient peoples' existential "freedom" - including those issues of individuality and individualization in ancient religions that have been so much debated in recent years. ${ }^{93}$ Lastly, Burkert intends to give an encompassing definition of the mystery phenomenon, hence the words that close his introduction:

Mysteries were initiation rituals of a voluntary, personal, and secret character that aimed at a change of mind through experience of the sacred. ${ }^{94}$

This definition intersects in part with a hermeneutic trend notably illustrated by Italian historians of religions, such as Ugo Bianchi and Dario Sabbatucci,

87 Alvar, Romanising Oriental Gods, 22 ("so far as we know, the cult of Mithras existed only in this form"), and Sfameni Gasparro, Misteri e teologie, 130 ("Solo per il mitraismo sarebbe legittimo usare la definizione di 'religione di mistero"), go as far as to argue that they constituted the model of "mystery" because of their complete secrecy.

88 See Françoise Van Haeperen infra, p. 194-217.

89 See infra p. 43-79 and 123-68 in this volume.

90 Cumont, Les religions orientales, 305 [189] and XXXIX-XLIV.

91 Burkert, Ancient Mystery Cults, 11.

92 Werner Jaeger, Paideia. Die Formung des griechischen Menschen (Berlin: De Gruyter, 1933-1947).

93 Cf. for instance Jörg Rüpke(ed.), The Individual in the Religions of the Ancient Mediterranean (Oxford: Oxford University Press, 2013).

94 Burkert, Ancient Mystery Cults, 11. 
and more recently Giulia Sfameni Gasparro. ${ }^{95}$ In this perspective, the distinctive features of mystery experience are the voluntary initiation of individuals, the secrecy that both isolates the initiate and makes him/her a member of a group, and a $\mu \varepsilon \tau \dot{\alpha} v o 1 \alpha$ ("a change of mind") following a peculiar experience. Again, such a definition raises several questions. It uses modern categories with diverse meanings (initiation, personal will, change of mind) that are used alongside ancient (emic) values. In 2003, Fritz Graf critically investigated the initiatory character of mysteries (which is the descriptive focus of Jan N. Bremmer's Initiation into the Mysteries in Ancient World), using the anthropological concept of rites de passage, and raising the questions of individual "initiation" and collective rituals for a whole age-group. ${ }^{96}$ But how can we articulate individual experience within a collective performance which paid no attention to age, in the case of the Eleusinian rites, paradigmatic for both Burkert and Bremmer? ${ }^{97}$ Moreover, if Eleusinian initiation promised a better life, as texts tell us, ${ }^{98}$ the representation of this life conforms to the common Greek imagery of the Elysian fields, ${ }^{99}$ with the exception of one (unique) piece of epigraphic evidence expressing a belief in a blessed after-life. ${ }^{100}$

A new reading of the mysteries has recently been developed, applying cognitive theories to the mystery experience, and focusing on the mental processes at work during the religious experience. Hugh Bowden's Mystery cults of the Ancient World adopts a global perspective once again, searching for the

95 Sabbatucci, Saggio sul misticismo, stressed the "rottura mistica" and the "rovesciamento di valori" that marked mystery cults as imported from outside Greece and were thus able to create a "counter-culture". Cf. for Rome Livy, 39, 13, 14, on the Bacchanalia as alterum iam prope populum. See also Bianchi, "Initiation"; Giulia Sfameni Gasparro, Soteriology and Mystic Aspects in the Cult of Cybele and Attis (Leiden: Brill, 1985), 6 and Ead., "Misteri e culti orientali: un problema storico-religioso," in Bonnet, Rüpke, and Scarpi (eds.), Religions orientales - Culti misterici, 181-210.

96 Graf, "Initiation" with a helpful historiographic overview. Alain Moreau (ed.), Linitiation. Actes du Colloque international de Montpellier (11-14 avril 1991), 1. Les rites d'adolescence et les mystères (Montpellier: Université Paul Valéry, 1992) uses the term very extensively, and comes to a phenomenological conclusion.

97 This is also the case at Andania in Messenia; see Laura Gawlinski, The Sacred Law of Andania. A new text with commentary (Berlin-Boston: De Gruyter, 2012).

98 See, for example, Aelius Aristides, Orations, 22 ('E $\lambda \varepsilon v \sigma i v 105)$ 10: "men having fairer hopes about death, that they will have a better existence and will not be in the darkness and

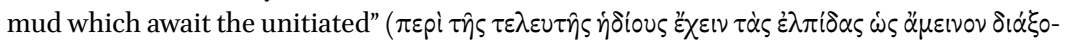

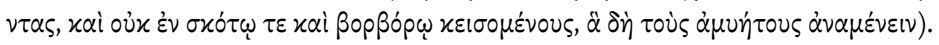

99 E.g. $I G \mathrm{II}^{2}{ }^{6} 63^{2}=$ IEleusis $5^{\mathrm{O} 2}=$ Kevin Clinton, "The Sacred Officials of the Eleusinian Mysteries," Transactions of the American Philosophical Society 64, 3 (1974), no. 10.

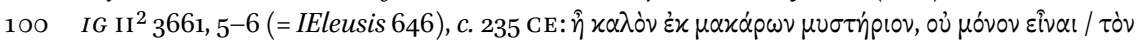

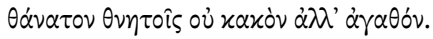


kind of knowledge that was provided by mystery rituals. ${ }^{101}$ He uses Harvey Whitehouse's theory of divergent modes of religiosity, which distinguishes between "imagistic" and "doctrinal" modes. ${ }^{102} \mathrm{He}$ sets his approach in the wake of the (somehow traditional) Burkertian definition of mystery that stresses a personal relationship between the divine figures and the initiates, driven by eschatological aspirations. Noting that evidence for secret knowledge largely pertains to philosophical literature, Bowden proposes the "theory of modes" as a way to overcome the discrepancies between various types of evidence and he examines the transmission of religious knowledge in terms of cognitive procedures. He considers that "the imagistic mode is a useful way of categorizing mystery cults", 103 insofar as mysteries were a direct experience of the divine, during which lived experience produced an internal transformation and gave access to a privileged (though not occult) knowledge. This mode would be relevant because mysteries are occasional rituals, weighted with an

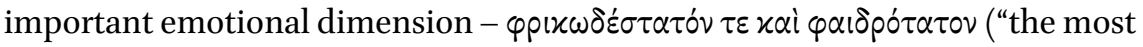
frightening and the most joyful") at Eleusis -104 that left an impression on the memory. 105 "I came out of the mystery hall feeling like a stranger to myself"

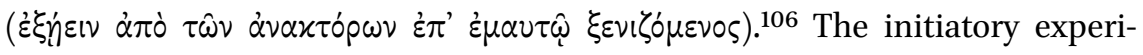
ence would cause a neurochemical reaction producing an episodic memory and a "spontaneous exegetical reflection". Emotions felt during the terrifying rituals of the initiation, ${ }^{107}$ analyzed with the model of traumatic experiences, would produce the knowledge of the initiation. ${ }^{108}$ This perspective is important when reading images, the more so frescoes in mithraea. Christian authors

101 Bowden, Mystery Cults. For similar inquiries, e.g. Blanka Misic, "Cognitive Theory and Religious Integration: The Case of the Poetovian Mithraea," in Tom Brindle, Martyn Allen, Emma Durham, and Alex Smith (eds.), TRAC 2014: Proceedings of the Twenty-Fourth Theoretical Roman Archaeology Conference, Reading 2014 (Oxford-Philadelphia: Oxbow, 2015), 31-40.

102 Harvey Whitehouse, Modes of religiosity. A Cognitive Theory of Religious Transmission (Walnut Creek, CA: AltaMira, 2004).

103 Bowden, Mystery Cults, 17.

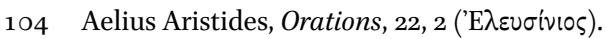

105 See also Martin H. Luther, "Cognitive science, ritual, and the Hellenistic mystery religions", Religion and Theology 13 (2006), 383-95 and Ustinova, Divine Mania, 132.

106 Sopater, Rhetores Graeci, 8, p. 115 (ed. Walz), transl. Burkert, Ancient Mystery Cults, 9o.

107 Terror and light/enlightment were the first features noted in discourses concerning the mysteries from Plato onwards; see Phaedrus, 25obc and supra n. 54. See also Ustinova, Divine Mania, 113-68 ("Telestic mania and near-death experience") who uses ancient textual and archaeological evidence uncritically and does not pay sufficient attention to the increasing mystery reading in philosophical discourses.

108 Contra, though applying a cognitive approach, Ustinova, Divine Mania, 116: "In any case, these objects, words and actions [in Eleusis] do not seem to have contained any 
stressed the emotional dimension, linking it with tragic myths, as Clement of Alexandria did in his long polemical discussion of the pagan mysteries. Eusebius of Caesarea quotes the whole passage with the title "On the unspeakable rites and the secret mysteries of the polytheistic imposture" (Пвpi $\tau \hat{\omega} \nu$

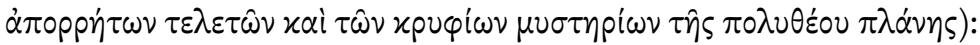

We ought to trace the etymologies of 'orgies' ( $\tau \dot{\alpha}$ öp $p / \alpha)$ and 'mysteries' ( $\tau \dot{\alpha}$ $\mu \nu \sigma \tau \dot{p} p(\alpha)$, the one from the anger ( $\dot{\alpha} \pi \dot{o} \tau \hat{\eta} s$ òprîs) of Deo aroused against Zeus, and the other from the pollution ( $\dot{\alpha} \pi \dot{\partial} \tau 0 \hat{\nu} \mu \dot{v} \sigma o v \varsigma)$ which had occurred with regard to Dionysus. Or even if you derive it from a certain Myus of Attica, who perished in hunting, as Apollodorus says, I do not grudge that your mysteries have been glorified by the honour of a name

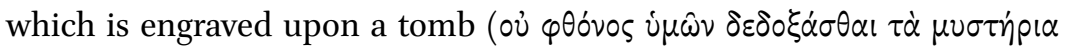
$\dot{\varepsilon} \pi(\tau \cup \mu \beta i \omega \tau \tau \mu \hat{\eta}){ }^{109}$

Taking a different approach, Jan N. Bremmer also focuses on initiation in his recent book. Structuring his discussion along chronological lines, he examines successively the "best-known mystery cults" (Eleusis, Samothrace, Cabires and Corybants, Orphism and the Orphico-bacchic mysteries, Greek mysteries in the Roman period, and later mysteries of Isis and Mithras), attempting "in as much detail as possible, to describe the[ir] actual initiation rituals". 10 In the Preface, he reminds readers that the term $\mu v \sigma \tau \dot{p}$ pla was used for the Eleusinian ceremonies from the beginning, ${ }^{111}$ and the whole book tends to demonstrate that Eleusinian Mysteries serve as the matrix for all the mysteries he studies. Therefore, the Eleusinian initiation process allows him to compensate for the lack of evidence for other mysteries in many cases, as in that of the Samothracian mysteries, to give one example (ch. 2). ${ }^{112}$ The method calls for caution as dem-

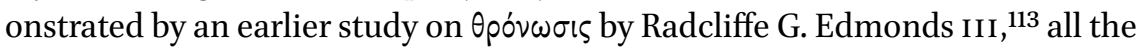
more so in the case of the Dionysiac rituals of the Hellenistic and Roman

life-changing revelation or knowledge that could potentially provide participants in the ceremonies with a release from the earthly evils, as Socrates said".

109 Clement of Alexandria, Proptrepticus, 2, 13, 1 = Eusebius of Caesarea, Preparation for the Gospel, 2, 3, 9-10, transl. LCL.

110 Bremmer, Initiation, XII.

111 Bremmer, Initiation, viI.

112 Bremmer, Initiation, 14 and 27.

113 Radcliffe G. Edmonds III, "To Sit in Solemn Silence? Thronosis in Ritual, Myth, and Iconography," The American Journal of Philology 127, 3 (2006), 347-66 demonstrates the extent to which the Eleusinian model can introduce confusion into our understanding of different rituals: "Beyond the basic importance of terminological accuracy, keeping the types of enthronement ritual separate is particularly important when analyzing other 
periods, and the use of literary texts, such as Pausanias, ${ }^{114}$ or Gnostic and Christian texts, ${ }^{115}$ calls for further critical examination.

Bremmer shows reverence to Burkert's book ("the most interesting contemporary study"), though he finds it "unsatisfactory" because of its lack of attention to "historical development",16 and he notes rightly the influence of Cumont's thinking on it:

nothing indicates that any such change of mind was involved in the Eleusinian Mysteries [...]. Burkert was evidently still under the influence of Cumont at this point. ${ }^{117}$

Like Burkert, Bremmer assumes a "voluntary character" in mystery cults. Moreover, focusing on initiation, he suggests that our very interpretative models are colored by Christian categories - a point that he does not, unfortunately, address except through a paper he refers to:

It is actually possible to show that the 'classic' modern term 'initiation', which scholars of religious studies are slowly beginning to discard, is, in fact, a Christian one. ${ }^{118}$

More broadly, Bremmer's book addresses two issues much debated today by historians of ancient religions: that of "individualization", and of the relationship between mystery cults and the so-called polis-religion. ${ }^{119}$ What is the nature of the change produced by initiation for the individual, and what are the effects of this change on the place and role of individuals within their social contexts? Considering that it is impossible to give a general definition

texts for allusions to Eleusinian rituals and using these allusions to try to reconstruct the rituals of the Mysteries" (348).

114 Pausanias, 1, 38, 7 (see supra n. 32) and 1, 14, 3 for the Athenian Eleusinion. On mystery cults in Pausanias, see Vinciane Pirenne-Delforge, Retour à la source. Pausanias et la religion grecque (Liège: Presses Universitaires de Liège, 2008), 291-346.

115 Massa (ed.), Mystery Cults and Heresies.

116 Bremmer, Initiation, XI.

117 Bremmer, Initiation, XI.

118 Katharina Waldner, "Dimensions of Individuality in Ancient Mystery Cults: Religious Practice and Philosophical Discourse," in Rüpke (ed.), The Individual in the Religions of the Ancient Mediterranean, 215-42, esp. 217, quoted by Bremmer, Initiation, XII.

119 Already raised in Jan N. Bremmer, "Manteis, Magic, Mysteries and Mythography: Messy Margins of Polis Religion?," Kernos 23 (2010), 13-35. 
of mystery cults because of their variety, ${ }^{120}$ Bremmer chooses to stress similarities, listing in the Preface the nine "general characteristics" of mystery cults that he envisions from different perspectives, that can be classified along four items: ritualistic (the cults make use of secrecy and an "emotionally impressive initiatory ritual", in line with a cognitive approach; they have a voluntary character, nocturnal performances, preliminary purifications, and payment for participation), interpretative (discussing "rewards promised for this life and life of the next", and an eschatological horizon, albeit asserted lightly), topographical (the older mysteries are located outside the cities), and sociological (the cults are open to all whatever status, gender and age, with the exception of the Mithras cult). ${ }^{121}$

Here is not the place to discuss these characteristics. Let us simply, to close these general considerations, point out the variety of places in which mysteries are found: in important extra-urban sanctuaries like in Eleusis, in non-monumentalized sites (Mount Solmissos, Ortygia for the mystikai thusiai performed by the Ephesian Curetes), ${ }^{122}$ in associative meeting places in the cities, and in the basements of private houses (Dionysiac or Mithraic rites for instance), and indeed anywhere, in the case of mystery rituals related to roaming priests, like the Orphic teletai discussed by Plato. ${ }^{123}$

\section{$4 \quad$ Mystery Cults and Visual Language: An Additional Challenge Framed by New Hermeneutic Tools}

The challenges of studying mystery cults are multiplied when these cults are examined from the perspective of images. This complexity might explain why the problem has not yet been tackled in a comprehensive way. The question is pertinent insofar as images and visual language were everywhere in both the

120 See already Vinciane Pirenne-Delforge and Paolo Scarpi, "Les cultes à mystères. Introduction," in Bonnet, Rüpke, and Scarpi (eds.), Religions orientales - Culti misterici, 161: mystery cults are not "un tipo assoluto, pur possedendo alcune caratteristiche che sembrano permettere di parlare di una tipologia misterica, in ogni caso circoscritta a un periodo e a un preciso contesto storico-culturale".

121 Bremmer, Initiation, 12 (our classification).

122 Strabo, 14, 1, 20.

123 Plato, Republic, 2, 364e. 
Greek - Athens was a "City of Images" - 124 and Roman worlds. ${ }^{125}$ Images of gods and of rituals (sacrifices, for instance) were ubiquitous in both their urban landscapes and their domestic contexts (not only in lararia), often in the most highly visible places. Yet when studying images of mysteries, the difficulty of studying concealed rituals is compounded by another one: images cannot be read as if they were simply products of a system of faith, as in modern Catholicism, and as if the image contains its own meaning and displays a literal illustration of its rituals or religious thinking. This was how Franz Cumont used images when he reconstructed the doctrine of the Mithraic mysteries:

représenter sur la pierre non seulement les divinités, mais la cosmogonie des mystères et les épisodes de la légende de Mithra jusqu'à l'immolation suprême du taureau. ${ }^{126}$

No iconic representation, not even a photograph, replicates reality. ${ }^{127}$ They are visual constructs telling an intellectual (speculative) or imaginative discourse of reality, which is thus shaped according to its cultural environment. This approach to deciphering the meanings of images - the "iconic turn" - was developed from the model of the linguistic (Saussurian) approach to the meaning of a text. We may note that the Greek verb үpá $\varphi \varepsilon$ iv means both "to write" and "to draw". A visual language thus uses the various elements that compose an image as signs to build systems of meaning and the conjunction of signs creates specific significations. Images have their own logic and expressivity, and

124 A City of Images. Iconography and Society in Ancient Greece (Princeton: Princeton University Press, 1989); first French ed. La Cité des images. Religion et société en Grèce antique (Lausanne-Paris: Fernand Nathan, 1984).

125 Cf. Paul Zanker, The Power of Images in the Age of Augustus (Ann Arbor: University of Michigan Press, 1988; first German ed. München: Beck, 1987); Tonio Hölscher, The Language of Images in Roman Art (Cambridge: Cambridge University Press, 2004; first German ed. Heidelberg: Carl Winter Universitätsverlag, 1987) and Id., Visual Power in Ancient Greece and Rome. Between Art and Social Reality (Oakland: University of California Press, 2018); Jas Elsner, Roman Eyes. Visuality and Subjectivity in Art and Text (Princeton, NJ-Oxford: Princeton University Press, 2007). For a sociological perspective, Paul Veyne, "Propagande expression roi, image idole oracle," in Id., La société romaine (Paris: Seuil, 1991), 311-42.

126 Cumont, Les Mystères de Mithra, 172.

127 See Anja Klöckner, "Votive als Gegenstände des Rituals - Votive als Bilder von Ritualen: Das Beispiel der griechischen Weihreliefs", in Jannis Mylonopoulos and Hubert Roeder (eds.), Archäologie und Ritual: auf der Suche nach der rituellen Handlung in den antiken Kulturen Ägyptens und Griechenlands (Wien: Phoibos, 2006), $139-52$. 
they display a polyvalent semantic system similar to that of texts. ${ }^{128}$ They show what their producers considered both worthy to be shown and capable of being understood when viewed. Yet viewers see images through their own cultural and imaginative background, and their act of viewing simultaneously constructs the image's meaning. ${ }^{129}$ Being signs with a whole range of possible values, the elements whose arrangement constitutes the image indicate

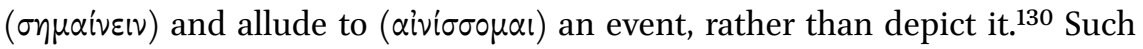
a perspective accords with the way in which ancient authors considered narratives about mysteries and myths: "mysteries and myths concerning the gods

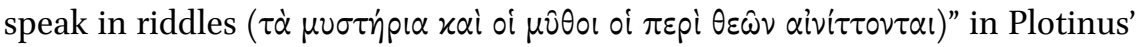
words. ${ }^{131}$ One century earlier, Lucian of Samosata depicted Zeus himself advocating for $\alpha i v i \gamma \mu \alpha \tau \alpha$ to be revealed to initiates during mysteria, after Momos had mocked the zoomorphic Egyptian gods. ${ }^{132}$ At the beginning of the fourth century, Eusebius conveyed this widely shared conception:

Hence, naturally, in all cities and villages, according to the narratives of these ancient authors ( $x \alpha \tau \dot{\alpha} \tau \dot{\alpha} \varsigma \tau \hat{\omega} \nu \pi \alpha \lambda \alpha \iota \hat{\omega} \nu \delta \eta \eta \eta \dot{\eta} \sigma \varepsilon ı)$ ), initiatory rites and mysteries of the gods corresponding to the mythical tales of the past

128 For semiotic readings of ancient evidence, Claude Bérard, Christiane Bron, and Alessandra Pomari (eds.), Images et société en Grèce ancienne: L'iconographie comme méthode d'analyse (Lausanne: Institut d'Archéologie et d'Histoire ancienne, 1987) and Claude Bérard, Embarquement pour l'image. Une école du regard, éd. et préface AnneFrançoise Jaccottet (Basel: Antike Kunst Beiheft 20, 2018), esp. 15-35 ("Iconography Iconologie - Iconologique").

129 See Bernd Stiegler, “Iconic Turn' et réflexion sociétale", Trivium 1 (2008), on line: http:// trivium.revues.org/308; Peter J. Bräunlein, "Ikonische Repräsentation von Religion", in Hans G. Kippenberg, Jörg Rüpke, and Kocku von Stuckrad (eds.), Europäische Religionsgeschichte (Göttingen: Vandenhoeck \& Ruprecht, 2009), 771-810. For viewing and subjectivity, see Elsner, Roman Eyes.

130 For instance, figures wearing animal masks on Mithraic reliefs do not imply that worshippers actually wore masks during the ceremonies, as regularly assumed on the basis of a passage in a problematic, late Christian text, Quaestiones veteri et novi Testamenti $114=$ Franz Cumont, Textes et Monuments figurés relatifs aux mystères de Mithra (Brussels: H. Lamertin, II, 1899), 8.

131 Plotinus, Enneads, 5, 1, 7, 33 (on the generation of Zeus by Kronos); for Eleusis, Clement of Alexandria, Protrepticus, 2, 12, 2 (the abduction of Persephone and the wandering of Demeter). See Nilsson, "The Bacchic Mysteries", 180: "Mystery rites were, when represented, generally concealed in a mythical guise". Mysteries were so much connected with a path to truth that hidden discourses were presented as full of truth, see Van Nuffelen, "Words of Truth".

132 Lucian, The Parliament of the Gods. 11, 1-6. 


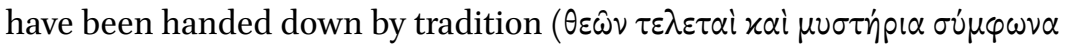

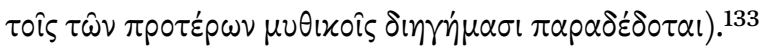

Images piece together selected visual elements, and they convey messages on various levels: ritual experience and space (to whose construction they contribute), ${ }^{134}$ mythological narratives, conception of the divine. They have long been used to reconstruct conceptions and practices of mystery cults. Cumont's Mystères de Mithra is exemplary in this regard. Yet, the studies which have followed Burkert's reexamination of mystery cults (see supra) have not addressed the issue of images of mystery cults. Rather, they have focused on a cultural analysis of the otherness and strangeness of "oriental" mysteries, ${ }^{135}$ although questions on the identification, and then "documentary" value, of images of mysteries are part of the larger problem of the relationships between religions and images, addressed both by archaeologists and historians of religions..$^{136}$

The investigation of images can complement our understanding of mysteries in the Graeco-Roman world, without starting from the etic conception scholarship has of ancient mysteries, already discussed above. We must avoid overinterpreting images when we too readily grant them a "mystical" significance. The depiction of the bath of Dionysos may serve as a warning: the scene should be contextualised, all the more so when it is found in a house, where it is one of a series of scenes narrating episodes of the life of the deity (his education by the Nymphs, the wedding banquet, the pompe returning from India, his drunkenness, the drinking contest with Heracles), as in the Dionysos mosaic at Sepphoris in Syria-Palaestina. ${ }^{137}$

\subsection{Images of Mysteries and Their Locations}

Not all the mysteries attested by texts have left images. For instance, the content of the $\mu \nu \sigma \tau \dot{p} \rho 1 \alpha$ of the Ephesian Artemis, well attested in inscriptions, and

133 Eusebius, Preparation for the Gospel, 15, 1, 2.

134 E.g. Eric M. Moormann, Divine Interiors. Mural Paintings in Greek and Roman Sanctuaries (Amsterdam: Amsterdam University Press, 2011).

135 See Elsner, Roman Eyes, 243-5.

136 E.g. Sylvia Estienne, Dominique Jaillard, Natacha Lubtchansky, and Claude Pouzadoux (eds.), Image et religion dans l'Antiquité gréco-romaine (Naples: Centre Jean Bérard, 2008); Ioannis Mylonopoulos (ed.), Divine Images and Human Imaginations in Ancient Greece and Rome (Leiden-Boston: Brill, 2010); Sylvia Estienne, Valérie Huet, François Lissarrague, and Francis Prost (eds.), Figures de dieux. Construire le divin en images (Rennes: Presses Universitaires de Rennes, 2014).

137 Rina Talgam and Zeev Weiss, The Mosaics of the House of Dionysus at Sepphoris (Jerusalem: Hebrew University of Jerusalem, 2004), 45-66, envision a "mystic" meaning. 
usually accompanied with sacrifices $\left(\theta v \sigma^{\prime} \alpha\right),{ }^{138}$ is only discussed in a single sentence in Strabo, who mentions the Curetes reenacting the birth of Apollo

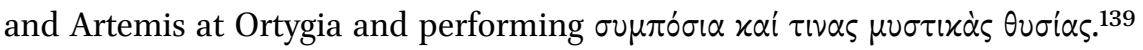
The rich iconography at Ephesus neither shows the episode nor alludes to it.

And yet, images of mysteries and mystery rituals were not restricted to cult places. They might be seen in accessible places. In Croatia, the tauroctony of the mithraeum of Močići was not hidden. It stands over a natural cave in an open space, and could be seen by any passer-by, proof that it was not considered by the members of the group as encapsulating a mystery-type dimension to be reserved to initiates. ${ }^{140}$ Admittedly we do not know the ritual use that was made of the iconographic "programs" of many tauroctony reliefs with predellas, ${ }^{141}$ and they are not consistent across all mithraea (with the exception of certain common features). As Gordon recently reminded us, ${ }^{142}$ Mithraic groups were autonomous, headed by a Father (Pater) with social influence, and made up of members with diverse cultural backgrounds. ${ }^{143}$ In a domestic context, the iconographic program of the so-called Villa of Mysteries at Pompeii (7О-6о вСЕ) is a famous and highly-debated example. The stunning murals painted on the triclinium walls of the Villa has received different interpretations. The traditional one, which gave its name to the villa, has it that the frescoes show a Dionysiac initiation. To put this reading in context, it is worth recalling that the discovery of the villa in 1909 coincided with the increasing academic popularity of Cumont's interpretation of the so-called oriental religions. More recently, Paul Veyne has interpreted the paintings as representing a marriage-related celebration held in the gynaecium of a Roman matron. ${ }^{144}$

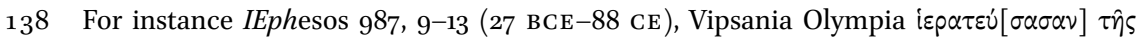

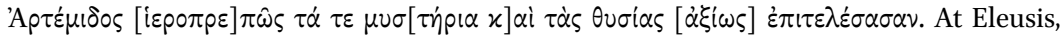
Cosmopoulos, Bronze Age Eleusis, 17 for the Lesser Mysteries: "The content of the ceremony involved sacrifices, dancing and singing, fasting, and sprinkling of water for purification, under the direction of the mystagogos".

139 Strabo, 14, 1, 20.

140 Stefanie Lenk, "Mithras - What is there to say," 2017, http://empiresoffaith.com/2017/04/14/ mithras-what-is-there-to-say/.

141 Attilio Mastrocinque, The Mysteries of Mithras. A Different Account (Tübingen: Mohr Siebeck, 2017), has three chapters ( 3 to $5,103^{-203}$ ) built on the images of the predellas of the tauroctony reliefs.

142 Richard L. Gordon, review of D. Walsh, The Cult of Mithras in Late Antiquity: Development, Decline and Demise ca. A.D. 270-430 (Leiden-Boston: Brill, 2018), ARYS 17 (2019), 466-7.

143 It suffices to compare the iconographic variety present in the same city (e.g. Ostia) or in a single area (e.g. in the Near East, the two different styles of the iconographic programs in the contemporary mithraea of Sidon [Greek] and Hawart [Persian]).

144 For the first hypothesis, see Gilles Sauron, La grande fresque de la Villa des Mystères à Pompéi. Mémoires d'une dévote de Dionysos (Paris: Picard, 1998); for the second, Paul 
Without dwelling on the details of the fresco, the least that can be said is that it seems indeed to evoke rituals related to the Dionysiac world.

\section{Mysteries and Visual Language: Two Case Studies Summing Up the Problematics}

Two case studies may be used to sum up the challenge that visual language poses for images of mysteries. Starting with Late Antique evidence, two cubic altars dating to the fourth century CE, found at Phlya, an Attic deme located to the North-East of Athens (modern Chalandri), show both inscriptions and images. ${ }^{145}$ According to the two inscriptions engraved on the altars, they were built to celebrate a taurobolium. The first and longest inscription consists of two epigrams written by a certain Archeleos who declares himself to be the first to dedicate an altar to Attis and Rhea after a taurobolium:

The rival of his ancestors, who elevated his great family even more by his own actions, Archeleos, knew gratitude in return $(\dot{\alpha} \nu \tau i \delta \circ \sigma \nu)$ for the rite of

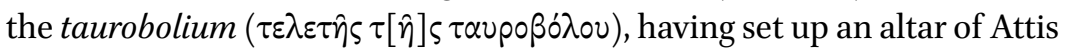
and Rhea. He is the pride of the Kekropian city; he dwells in Argos living

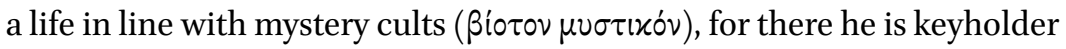
of Queen Hera, and in Lerna he received the torches that solemnize the

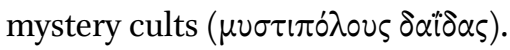

vac.

As dadouch of Kore, carrying the sacred keys of Queen Hera's shrine, Archeleos dedicated me, this altar, to Rhea, having engraved hidden tokens ( $\sigma \nu v \theta \dot{\eta} \mu \alpha \tau \alpha \varkappa \rho \nu \pi \tau \dot{\alpha})$ of the taurobolium rite, performed here for the first time. ${ }^{146}$

Veyne, "La fresque dite des mystères à Pompéi," in Paul Veyne, François Lissarrague and Françoise Frontisi-Ducroux (eds.), Les mystères du gynécée (Paris: Gallimard, 1998), 13-153 and Paul Veyne, La Villa des mystères à Pompéi (Paris: Gallimard, 2016).

145 See Éveline and Ioannis Loucas, "Un autel de Rhéa-Cybèle et la Grande Déesse de Phlya," Latomus 45, 2 (1986), 392-404; Katerina Rhomiopoulou, National Archeological Museum. Collection of Roman Sculpture (Athens: Archeological receipts fund, 1997), 83; Helen Saradi-Mendelovici, "Late Paganism and Christianization in Greece," in Luke Lavan and Michael Mulryan (eds.), The Archaeology of Late Antique Paganism (Leiden-Boston: Brill, 2011), 263-309, esp. 286-7; and Françoise Van Haeperen, "Prêtre(sse)s, tauroboles et mystères phrygiens," in Estienne, Huet, Lissarrague, and Prost (eds.), Figures de dieux, 99-118.

$146 I G \mathrm{II}^{2} 4841=\mathrm{II}^{2} \mathrm{~V} 13253$ (transl. AIO: www.atticinscriptions.com/inscription/IGII25/13252, slightly modified). 
The second, shorter, inscription says that Mousonios has dedicated the altar to Attis and Rhea on the occasion of a taurobolium.

Under the consulship of Honorius and Euodius, on the twenty-seventh of May, when Hermogenes was archon, the taurobolium was performed in Athens, having undertaken which, I, Mousonios, the most illustrious,

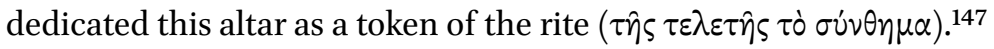

The reference to the consulate of Honorius and Euodius dates the ceremony to May, 27th 386/7, which consequently implies an older date for the Archeleos' altar, since he boasts of having been the first to celebrate a taurobolium. Only the poetic inscription of Archeleos emphasizes the vocabulary of mystery cults, while Mousonios uses the encompassing term $\tau \varepsilon \lambda \varepsilon \tau \dot{\eta}$ to evoke the performed ritual. Archeleos stresses the mystery aspect of his ritual: he pursues a mystikos life and received the mystipoloi torches during a celebration of Demeter's mystery cults in Lerna. ${ }^{148}$ His engagement in mystery cults is strongly emphasized. He expresses a close link between the telete of the taurobolium and the world of mystery cults, evoked through the reference to $\sigma u v \theta \dot{\eta} \mu \alpha \tau \alpha \varkappa p \nu \pi \tau \dot{\alpha}$, the "hidden symbols" related to the unspeakable and secret of mystery cults.

Leaving the text to examine the figural decoration, what image of the ceremony is conveyed by the reliefs sculpted on the sides of the altars? How do they refer to the ritual practices mentioned in the inscriptions? The rear side of the two altars features the same iconographic pattern: two seated gods in the centre and two figures, female and male, on either side. The seated goddesses likely represent Rhea/the Mother, on the right, while Demeter is on the left. Rhea is identifiable by her turret crown, the canopy she holds in her right hand, and the tympanum in her left. Demeter is recognizable by the wheat ear in her right hand and the snake coiled around the torch she holds. The two other figures holding torches might be Kore or Hecate and Iacchus or Attis. Besides their identities, the gestures of the depicted characters are worthy of attention. The position of the torches (up and down) suggests a lit/unlit opposition, and

\footnotetext{
$147 I G \mathrm{II}^{2} 4842=\mathrm{II}^{2} \mathrm{~V} 1325^{2}$ (transl. AIO: $w w w . a t t i c i n s c r i p t i o n s . c o m / i n s c r i p t i o n / I G I I 25 / 13253$, slightly modified).

148 Cf. Pausanias, 2, 36-37. On these cults, see Martin P. Nilsson, The Dionysiac Mysteries of the Hellenistic and Roman Age (Lund: Gleerup, 1957), 49; Marcel Piérart, "La mort de Dionysos à Argos," in Robin Hägg (ed.), The Role of Religion in the Greek Polis (Stockholm: Aströms, 1996), 141-51; Albert Henrichs, "Hieroi Logoi and Hierai Bibloi: The (Un)written Margins of the Sacred in Ancient Greece," Harvard Studies in Classical Philology, 101 (2003), 207-66, esp. 243-4, and Pirenne-Delforge, Retour à la source, 299-304.
} 
thus a contrast between light and dark, ${ }^{149}$ which is a foundational aspect of the secret elements typical of mystery cults. Giving access to a form of knowledge that goes under the name of epopteia, revelation, or gnosis, ${ }^{150}$ is indeed one of the features traditionally attributed to mystery cults. This transformative dimension, which is one of the three specific features of mystery cults identified by Walter Burkert, ${ }^{151}$ has to be taken into account in the analysis of each of the mystery cults of the Roman period.

The front of the two altars leads us back to the myths evoked in the engraved text, and more broadly to the cult of Rhea/Mother of gods (fig. 1.1-1.2).

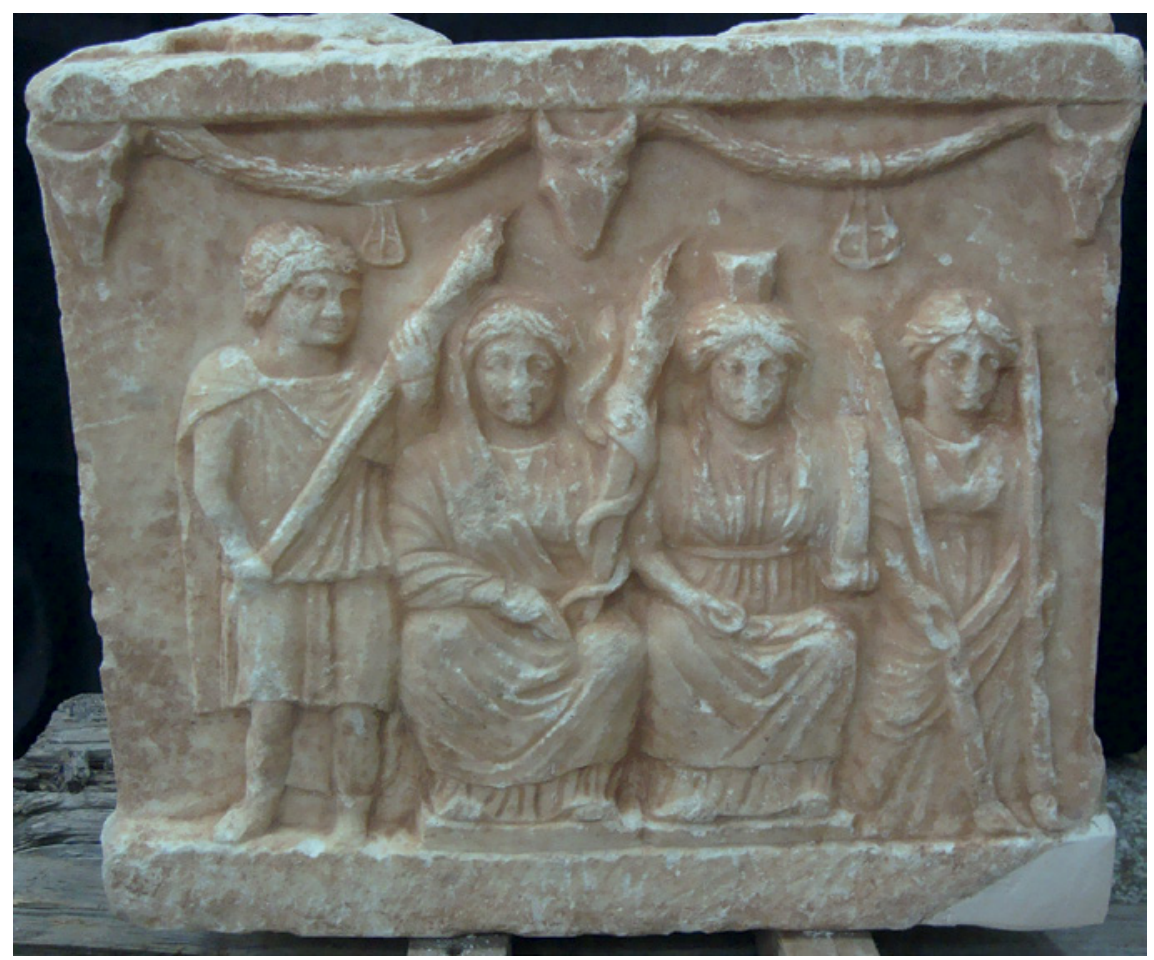

FIGURE 1.1 Taurobolic altar (Archeleos), National Archaeological Museum of Athens, n. 1746. Front side. Photo (C) National Archaeological Museum of Athens

149 See Menelaos Christopoulos, Efimia D. Karakantza, and Olga Levaniouk (eds.), Light and Darkness in Ancient Greek Myth and Religion (Lanham-Boulder-New York: Rowman \& Littlefield Publishers Inc. 2010).

150 See Ustinova, Divine Mania, 129: "the numinous experience of inner vision, the supreme epopteia which changed one's attitude to life and death".

151 See supra n. 94. 


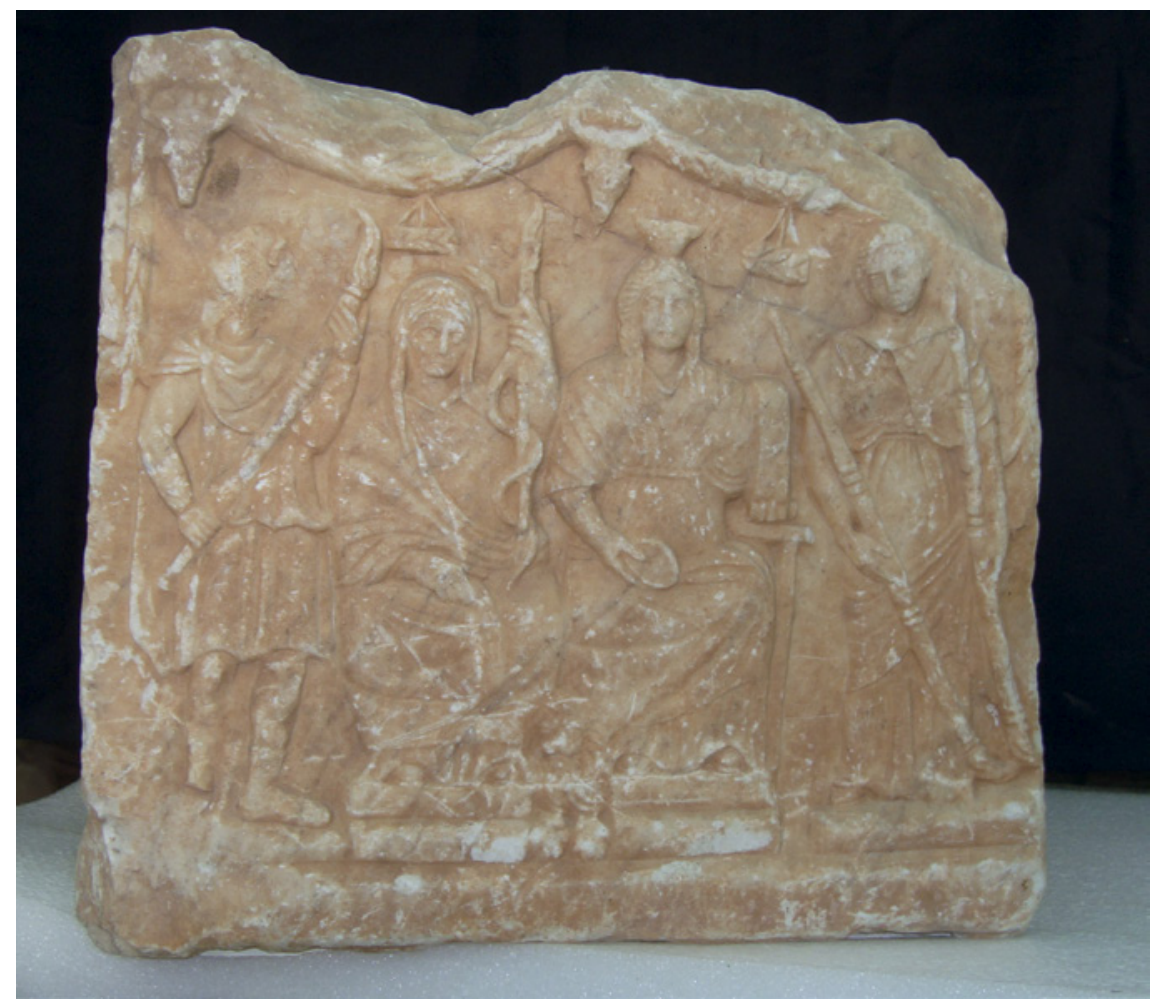

FIgURE 1.2 Taurobolic altar (Mousonios), National Archaeological Museum of Athens, n. 1747. Front side. Photo (C) National Archaeological Museum of Athens

This cultic evocation is even more explicit in the right side of both altars (fig. 1.3). The viewer sees several ritual objects, such as two crossed torches, a canopy and a pot, possibly an urceus on the top part, and a tympanum and pedum below.

Might these instruments serve to indicate that the altar served as a site for the celebration of a secret, mystery-type ritual? To what extent do the images correspond to a visual representation of a mystery cult? Or is it rather the text and its explicit references to a 'mystery' ritual that support the memory of a mystery experience? The third part of this book will propose some answers. ${ }^{152}$

The reader will not be surprised that our second case study illustrating the problematic of this book 'on the ground' returns to Mithraic images, "notre source d'information principale dans l'étude du mithriacisme" in Cumont's

152 See infra p. 169-217. 


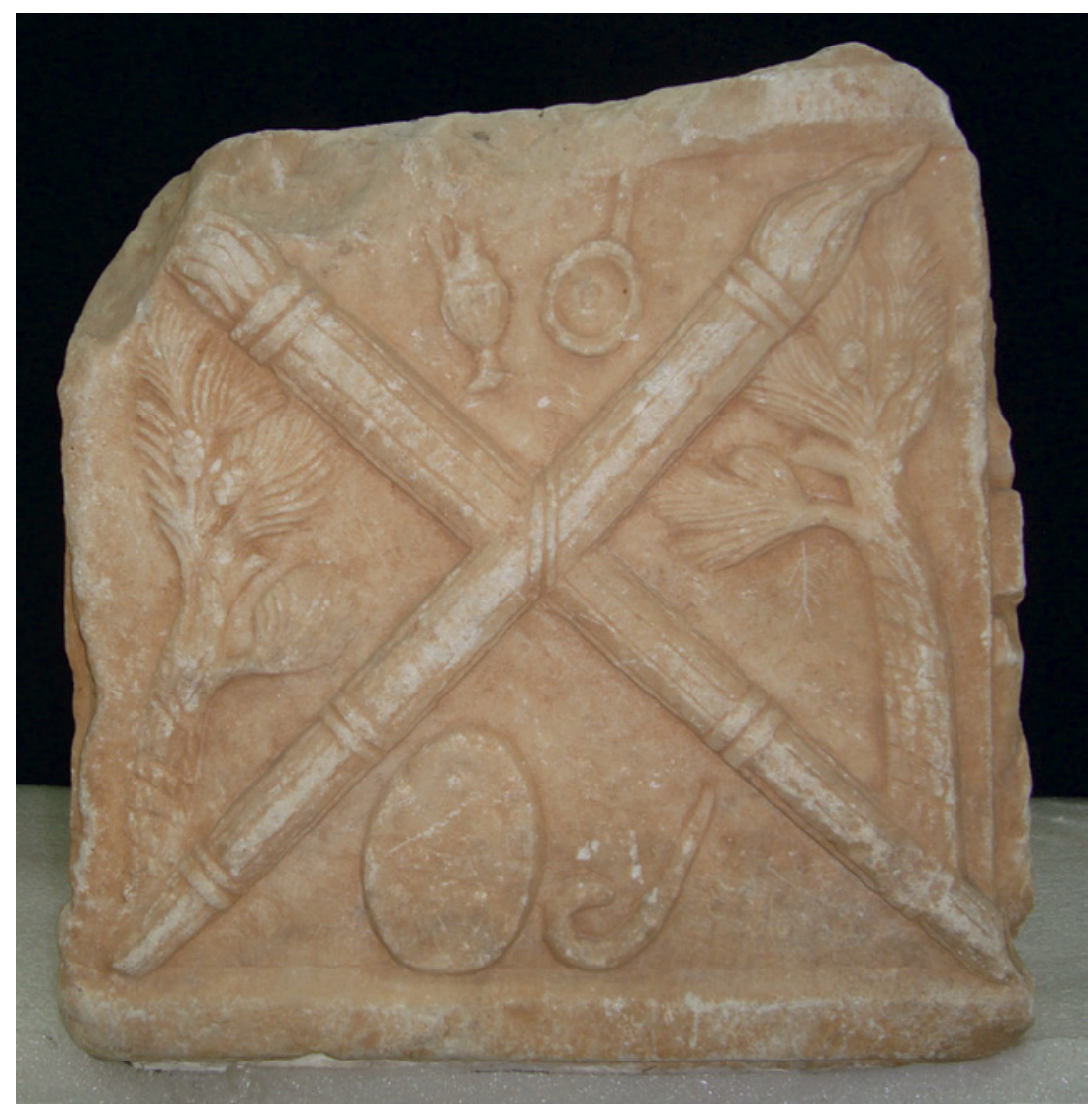

FIgURE 1.3 Taurobolic altar (Mousonios), National Archaeological Museum of Athens, n. 1747. Right side. Photo (C) National Archaeological Museum of Athens

thinking. ${ }^{153}$ The case is emblematic inasmuch as Cumont tried to use images to reveal what he did not find in texts, ${ }^{154}$ namely explicit attestations of "mysteries", and of their "doctrine" and "liturgy". 155 He was confident in the ability

153 Cumont, Textes et Monuments, II, 53. See supra n. 13-15.

154 The unique attestation of the term telete is found in the dedication of the tauroctony of Sidon, in the third quarter of the fourth century CE, CIMRM I, no. 76. The Latin vocabulary is not much more explicit, except for the grades; see supra $\mathrm{n} .68$.

155 The method has recently been contested; see Roger Beck, The Religion of the Mithras Cult in the Roman Empire, 17-25. Cf. Philippa Adrych, Robert Bracey, Dominic Dalglish, Stefanie Lenk, and Rachel Wood, Images of Mithra (Oxford: Oxford University Press, 2017), 9-10, which places a pertinent emphasis on the fact that many Mithraic reliefs have 
of images to contribute information, and to enlighten his major horizon, the interactions between Mithraism and Christianity in the wake of the competitive reconstruction which Ernest Renan had proposed. ${ }^{156}$ He considered that reliefs narrated the myth - envisioned within a Mazdaean religious system (a "forme romaine du mazdéisme") - 157 and gave access to the "doctrine des mystères" (the title of his fourth chapter). Although his conception has been (more or less) abandoned today, the question of the relationship between myth, rite, and images remains valid, and it informs all of the studies in this volume.

Cumont did not know, of course, of the frescoes of the mithraea uncovered after the Second World War - those of Santa Prisca in Rome and Santa Maria Capua Vetere -, ${ }^{158}$ or the vase (a crater) with a serpent (Schlangengefäss) discovered in Mainz in 1976, displaying figures in the course of an initiatory ritual. ${ }^{159}$ Deciphered through the lense of ancient texts (some of them of a later date) which evoke terrifying experiences, ${ }^{160}$ these images have been interpreted as picturing some of the steps of Mithraic initiation. Very recently, frescoes of the mithraeum of Caesarea Maritima in Syria-Palaestina have been published. ${ }^{161}$ The authors modeled their decipherment on the existing interpretations of the frescoes of Rome and Capua, despite the fact that these interpretations were in turn based on a literary corpus which included many

been restored according to a modern model of Mithras mysteries, and have thus contributed to the maintenance of a debatable reconstruction (e.g. 19-24). See also Philippa Adrych in this volume p. 103-122.

156 Cumont, Les Mystères de Mithra, 107. Of course, Cumont is "Winckelmannist" when reading images, see his appendix on "l'art mithriaque", Cumont, Les Mystères de Mithra, 221-38. A recent radically opposite - Roman - reading by Attilio Mastrocinque, The Mysteries of Mithra. A Different Account (Tübingen: Mohr Siebeck, 2017).

157 He looked in the Zend Avesta for a literal account, a "commentaire pour interpréter la masse considérable de monuments figurés", Cumont, Les religions orientales, Pref. 5 (we underline).

158 Marteen J. Vermaseren and Carel C. Van Essen, The Excavations in the Mithraeum of the Church of Santa Prisca in Rome (Leiden: Brill, 1965), and Vermaseren, Mithriaca I. The Mithraeum at S. Maria Capua Vetere.

159 Dated to 120-140 CE, Roger Beck, "Myth, Doctrine, and Initiation in the Mysteries of Mithras: New Evidence from a Cult Vessel", Journal of Roman Studies 90 (2000), 145-80, and Ingeborg Huld-Zetsche, Der Mithraskult in Mainz und das Mithräum am Ballplatz (Mainz: Generaldirektion Kulturelles Erbe, Direktion Archäologie, 2008), figg. 11-2.

16o See supra n. 53, with the reservations of Richard Gordon.

161 Robert J. Bull, with Jane Derose Evans, Alexandra L. Ratzlaff, Andrew H. Bobeck, Robert S. Fritzius, The Mithraeum at Caesarea Maritima (Boston: The American Schools of Oriental Research, 2017). 
polemical Christian authors, ${ }^{162}$ assuming that there existed a "standardized iconographic visual program" in all mithraea, and the prescriptive authority this implies. As in Cumont's Mystères de Mithra, decontextualized discourses (explicitly symbolic in Porphyry's words) ${ }^{163}$ are applied to images. The authors identify a chronological narrative of the initiation of the leones, the first of the higher grades according to Gordon. They read the three sequences which they identify through the initiatory model of a near-death experience, provoking the transformation of the initiate. Yet they class every ritual stage, including the procession, ${ }^{164}$ as "initiations", even though the parallel of the festival with the mysteries at Andania (Messenia) invites us to distinguish the different stages. ${ }^{165}$ At Santa Prisca, the procession takes place when the Lions are acclaimed, ${ }^{166}$ but we do not know if this was in order to congratulate an "initiation" or a promotion to a higher grade. This is not the place to enter into a deeper analysis of these fascinating frescoes. ${ }^{167}$ Yet these artefacts support the preliminary aim of this book: identifying what is "mystery" or "initiatory" in so-called images of mysteries.

This introductory essay has attempted to set the stage for images, visual signs and symbols in mystery cults. It has warned of the methodological problems that necessarily accompany mystery cults because of their many specificities: secrecy, texts which speak through riddles, the imaginaire of mysteries produced by a long historiography, the dominance of an Eleusinian model, and the arguably superior ability of the visual language to communicate the mysteries or mystery-type experiences. In this respect, regardless of potential biases, it has underlined the importance of visual language in recounting an

162 For instance Panel B (Bull et al., The Mithraeum at Caesarea Maritima, 45-6), either a "firetest" if we depend on Tertullian's anti-gnostic treatise, Against Marcion, 1, 13, 5 (sicut aridae et ardentis naturae sacramenta leones Mithrae philosophantur), or a purificatory rite with honey if we use the work of the Neoplatonist Porphyry, The Cave of the Nymphs, 15-16

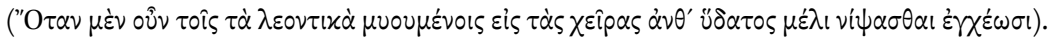

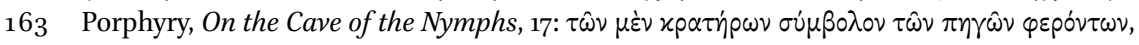

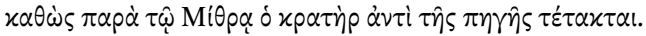

164 Bull et al., The Mithraeum at Caesarea Maritima, 44 ("The elements of this scene depict a procession. The composition has parallels to known images of initiation practices (Santa Maria Capua Vetere, Konjic) and should therefore be interpreted as a scene from an initiation ritual") and 47 ("Taken together, the three panels represent an initiation").

165 Supra n. 97.

166 See recently Moormann, Divine Interiors., $163-83$.

167 Cf. the "group identity" reading by Nicole Belayche, "Quelques réflexions sur textes et images," in Anne-Françoise Jaccottet (ed.), Rituels en images / Images de rituels (Genève: EGEA, 2021). 
experience that is beyond words, an experience which consists of visual and aural perceptions, even if words $(\lambda \varepsilon \gamma o ́ \mu \varepsilon v \alpha)$ were spoken.

The following contributions in this collective study share a common method, combining a semiotic reading of images with a socio-anthropological approach, paying attention to the materiality of the image, its historical and religious context, its producers and viewers. We will address the visual representation of mysteries in three parts, each tackling one of three, unequally documented, issues in the various mystery cults:

I) Thanks to the quantity of evidence, Dionysiac imagery examined over the longue durée is the most promising field in which to set reflexive accounts: how can images depict a "mystery", and what are the devices they use to do so? 168

II) The interrelated questions of historiography and the use of images of mystery cults are better understood when the focus is put on the "mysteries" of the Roman imperial period: Mithras and the Isiac "mysteries".169

III) Finally it will be time to concentrate on pictures of specific objects that play the role of markers for recounting "mysteries" in images, as demonstrated by the $\lambda$ ix vov (we recall that Dionysos can be called Liknites) $)^{170}$ and the $x i \sigma \tau /$ cista. ${ }^{171}$

This collective inquiry was a collaboration, and so last we have the pleasure of thanking warmly all of the colleagues who shared in this endeavour, first and foremost our contributors. Collective studies need support, which we received from the École Pratique des Hautes Études (PSL Paris), the research team Anthropologie et histoire des mondes anciens (UMR 8210 / CNRS), the Swiss National Science Foundation, and the University of Geneva. Moreover, our sincere thanks go to the editors who accepted this book into this incomparable series, "Religions of the Graeco-Roman World" - a worthy heir to the "Études préliminaires aux religions orientales" (EPRO), which produced many pioneering studies of the topics addressed in this book, as the notes which follow will clearly show. And last, but not least, our special thanks go to Thomas Galoppin who assisted in the preparation of the manuscript with his usual generous and discrete efficiency. Special thanks are due also to Tessa Schild, who was an attentive and patient editorial partner from the beginning.

168 Cornelia Isler-Kerényi, Stéphanie Wyler and Janine Balty in this volume, p. 43-61, 62-79 and $80-98$.

169 Philippa Adrych and Richard Veymiers in this volume, p. 103-22 and 123-68.

170 Martin P. Nilsson, "The Bacchic Mysteries of the Roman Age," Harvard Theological Review 46 (1953), 182-3.

171 Anne-Françoise Jaccottet and Françoise Van Haeperen in this volume, p. 173-93 and 194-217. 